\title{
Perspectivas transatlánticas de una serie pasionaria del pintor novohispano José Ibarra (1685-1756)
}

\author{
Transatlantic Perspectives of a Passion Cycle from the New \\ Spanish Painter José de Ibarra (1685-1756)
}

\section{Alena Robin ${ }^{1}$ \\ Western University, Canada}

\begin{abstract}
Resumen: Este artículo estudia un ciclo pasionario firmado y fechado en 1744 por el afamado pintor novohispano José de Ibarra. El conjunto de 15 lienzos, ahora en una colección particular, no había sido catalogado dentro de la producción pictórica conocida del maestro. La serie fue adquirida por un exitoso mercader español activo en el puerto de Veracruz en la segunda mitad del siglo XVIII. El ciclo ilustra consideraciones de transferencias culturales en el mundo hispano de aquella época y sugiere cuestionamientos en relación a los modelos globales de comunicación y de intercambio. La serie se analiza aquí desde varias perspectivas transatlánticas, incluyendo la apropiación por parte del pintor novohispano de fuentes grabadas flamencas e italianas.
\end{abstract}

Palabras clave: Pasión de Cristo, pintura novohispana, José de Ibarra, grabados, transferencias culturales, estudios transatlánticos.

Abstract: This article analyzes a Passion cycle signed and dated in 1744 by the notorious New Spanish painter José de Ibarra. The set of 15 canvases, now in a private collection, had not been catalogued in the work of the master. The cycle was acquired by an important Spanish merchant, active in the port of Veracruz in the second half of the eighteenth century. The cycle illustrates considerations on cultural transfers in the Hispanic world of the era and raises questions in relation to global models of communication and exchange. The series is analyzed from Transatlantic perspectives, including the appropriation by the New Spanish painter of Flemish and Italians engravings.

Key-words: Passion of Christ, New Spanish painting, José de Ibarra, engravings, cultural transfers, Transatlantic Studies.

1 (1) http://orcid.org/0000-0003-3997-1472

(C) 2019 Philostrato. Revista de Historia y Arte 


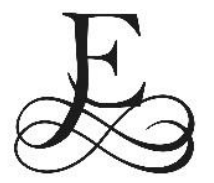

ste artículo estudia un ciclo pasionario pintado a mediados del siglo XVIII en el virreinato de Nueva España. ${ }^{2}$ La serie pictórica ilustra consideraciones acerca de las transferencias culturales en el mundo hispano de aquella época y sugiere el cuestionamiento y discusión de los modelos globales de comunicación y de intercambio. El ciclo de 15 lienzos está fechado en 1744, y firmado por José de Ibarra (1685-1756), un destacado pintor del momento. El conjunto no había sido catalogado dentro de la producción pictórica conocida del maestro novohispano, ya que se encuentra en una colección particular. Se considera que fue adquirido por Tomás Barbadillo Subiñas (Covarrubias, España, 1737 - Veracruz, México, 1808), quien se instaló en el virreinato de Nueva España hacia 1760-1770, donde desarrolló una importante actividad mercantil en Veracruz.

En esta ocasión, pretendo dar a conocer el conjunto de pinturas que no ha sido estudiado hasta el momento, analizándolo desde sus perspectivas transatlánticas. Considero la figura del autor y cómo la serie viajó hacia España, así como la apropiación de fuentes grabadas europeas, principalmente flamencas e italianas, por parte del pintor novohispano. También abordo algunas consideraciones acerca de Tomás Barbadillo, contextualizando su actividad en el puerto de Veracruz. Termino aludiendo a otra serie pasionaria que se conserva en la Casa Profesa de la Ciudad de México cuyo parecido con el ciclo inédito ideado por Ibarra es asombroso.

\section{José de Ibarra (1685-1756)}

Desde hace mucho tiempo se reconoce la importancia de José de Ibarra en la tradición pictórica novohispana, dado que constituye un eslabón fundamental entre diferentes generaciones y dinastías de pintores. No obstante, la figura de José de Ibarra como intelectual prominente de la pin-

\footnotetext{
${ }^{2}$ Agradezco a los propietarios las facilidades que se me han proporcionado para la observación directa y el estudio detallado de los cuadros que conforma la serie. Agradezco también la ayuda recibida por la restauradora Consuelo Olaguibel, y de María Laura Flores Barba e Iván Baruj Vázquez Clavellina, ayudantes de investigación en Western University. También agradezco a Flor Trejo y el personal de la Biblioteca de arqueología subacuática en la Ciudad de México que me permitieron consultar su biblioteca especializada. Parte de esta investigación se ha presentado en los siguientes congresos y agradezco las preguntas y comentarios del público que enriquecieron mi reflexión: Universities Art Association of Canada (Waterloo, 2018), Sixteenth Century Society and Conference (Albuquerque, 2018), IV Simposio Internacional Jóvenes Investigadores del Barroco Iberoamericano (Cáceres, 2019). Agradezco el apoyo recibido por Western University para desarrollar esta investigación.
} 


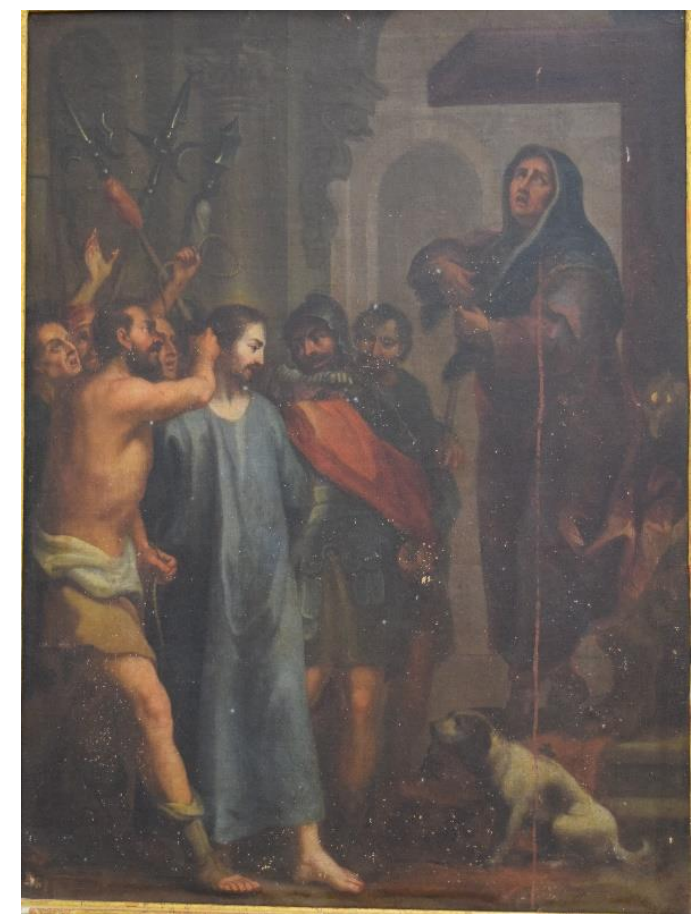

Fig. 1. José de Ibarra, Jesús ante Caifas, 1744, Colección particular. (C) Alena Robin

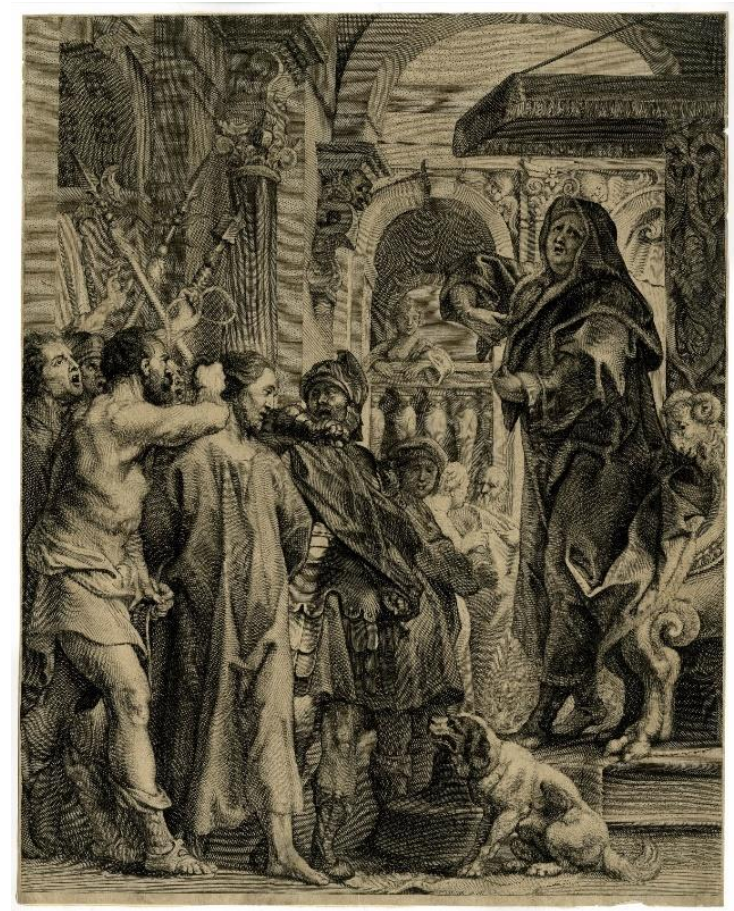

Fig. 2. Marinus Robyn Van der Goes siguiendo a Jacob Jordaens, Jesús ante Caifas, 1614-1639, British Museum. (C) The Trustees of the British Museum. (Shared under a Creative Commons Attribution-NonCommercial-ShareAlike 4.0)

tura novohispana del siglo XVIII fue rescatada recientemente gracias a los estudios de Paula Mues ${ }^{3}$.

Originario de la ciudad de Guadalajara, la capital del reino de Nueva Galicia, Ibarra pasó joven a la Ciudad de México, donde completó su formación artística. Aunque nombra a Juan Correa (c. 1645-1716) como su maestro, un importante pintor de finales del siglo XVII, se ha reconocido en sus obras más bien una afiliación formal con las de los hermanos Nicolás (1667-1734) y Juan Rodríguez Juárez (1675-1728) ${ }^{4}$. Es posible que Ibarra haya trabajado en el taller de Juan Correa hasta la muerte del maestro y entonces terminase su

\footnotetext{
${ }^{3}$ Paula Mues Orts, El pintor novohispana José de Ibarra: Imágenes retóricas y discursos pintados, 4 vols (Ciudad de México: Facultad de Filosofía y Letras, UNAM, tesis de doctorado en Historia del arte, 2009) y Paula Mues Orts, José de Ibarra. Profesor de la nobilísima arte de la pintura, (Ciudad de México: Consejo Nacional para la Cultura y las Artes, 2001).

${ }^{4}$ La declaración de Ibarra está registrada en el texto de su pupilo y amigo Miguel Cabrera sobre la Virgen de Guadalupe, Miguel Cabrera, Maravilla americana y conjunto de raras maravillas... (Ciudad de México: Imprenta Real y más antiguo Colegio de San Ildefonso, 1756), p. 10.

Sobre Juan Correa, véase el monumental trabajo de Elisa Vargaslugo et al., Juan Correa. Su vida y su obra, 4 vols., (Ciudad de México: UNAM/ IIE, 1985-2017).

Para una visión panorámica de la pintura novohispana, véase Rogelio Ruiz Gomar, "Unique Expressions. Painting in New Spain" en Painting a New World, ed. Donna Pierce, Rogelio Ruiz Gomar, Clara Bargellini, (Denver: Denver Art Museum, 2004), pp. 47-77; Luisa Elena Álcala y Jonathan Brown, Painting in Latin America, 1550-1820, (New Haven: Yale University Press, 2014), en particular los capítulos 1-5 y los estudios incluidos en el catálogo de la exposición: Painted in Mexico, 1700-1790: Pinxit Mexici, ed. Ilona Katzew, (Los Ángeles/ Ciudad de México: Los Ángeles County Museum of Art/ Fomento Cultural Banamex, 2017).
} 
formación con el también afamado pintor Juan Rodríguez Juárez. El primer trabajo independiente de Ibarra se fecha en 1728, circunstancia que coincide con la muerte de Juan Rodríguez Juárez. Los hermanos Rodríguez Juárez formaron parte de una dinastía de pintores que se remonta a Luis Juárez (ca. 1585-1639) y propusieron un nuevo estilo pictórico que coincidió con el cambio de siglo y de monarquía. Este estilo fue consolidado por Ibarra y perduró a lo largo del siglo XVIII.

A pesar de que su carrera empezó tarde, Ibarra fue un pintor prolífico y atendió una clientela amplia, tanto del mundo religioso como del civil. Ilustró en sus obras una multitud de temas, tanto devocionales como retratos, y su vasta producción está actualmente dispersa en iglesias, museos, y colecciones privadas en México, Estados Unidos, España, etc. ${ }^{5}$ Entre 1734 y 1741, Ibarra mantuvo una relación cercana con el virrey Juan Antonio de Vizarrón (1682-1747), de quien hizo varios retratos. Asimismo, se conoce que Ibarra fue amigo cercano del erudito y humanista novohispano Cayetano Cabrera y Quintero (ca. 1695-1778). Además fue el responsable de la traducción del italiano al español de un tratado artístico del jesuita italiano Francesco Lana (1631-1687) ${ }^{6}$. Estos hechos demuestran que Ibarra estuvo rodeado y participó en la élite intelectual del momento: jugó un papel fundamental para elevar el estatuto de pintores de la Ciudad de México, un tema estudiado en detalle por Paula Mues.

Ibarra pasó a la posteridad con varios apelativos que aluden al aprecio del que gozó entre sus contemporáneos. Cayetano Cabrera y Quintero fue quien lo comparó con el pintor andaluz Bartolomé Esteban Murillo (1617-1682) pero también se conoció a Ibarra como "el Correggio americano" haciendo referencia al pintor italiano Antonio Allegri da Correggio (1489-1534). ${ }^{8}$ Estos apelativos no implican que Ibarra pintara a la usanza de estos pintores europeos, sino que el novohispano fue paragonado con estos artistas de primera fila para enfatizar su posición de autoridad en la pintura del momento.

\footnotetext{
${ }^{5}$ Existen, por ejemplo, dos cobres de Ibarra en una colección particular sevillana, cfr. Gerardo Pérez Calero, "Dos obras desconocidas del pintor mejicano José Ibarra," Gades, Revista del Colegio Universitario de Filosofía y Letras de Cádiz, 9, (1982), pp. 267-270.

6 Paula Mues Orts, El arte maestra: traducción novohispana de un tratado pictórico italiano, (Ciudad de México: Museo de la Basílica de Guadalupe, 2006).

7 Por ejemplo, en 1754 obtuvo, junto a varios pintores, el apoyo real para fundar una academia de arte. Si bien el grupo no tuvo éxito, al no conseguir un apoyo explícito en ese momento, la academia funcionó de manera independiente. Xavier Moyssén, "La primera academia de pintura en México", Anales del Instituto de Investigaciones Estéticas, 9, 34, (1965) pp. 15-29; Paula Mues Orts, La libertad del pincel. Los discursos sobre la nobleza de la pintura en Nueva España, (Ciudad de México: Universidad Iberoamericana, 2008). Estos proyectos, en los que Ibarra destacó como figura primordial, fueron decisivos para la fundación de la Real Academia de San Carlos en 1783.

${ }^{8}$ Paula Mues Orts, "Illustrious Painting and Modern Brushes" en Painted in Mexico, p. 63. Sobre la influencia de Murillo en la pintura novohispana, véase Paula Mues Orts, "De Murillo al murillismo o del cambio en la mirada: guiños sobre la suavidad y la gracia en la pintura novohispana" en Andalucía en América Arte y Patrimonio, ed. Rafael López Guzmán, (Granada: Editorial Atrio, 2012), pp. 47-72.
} 


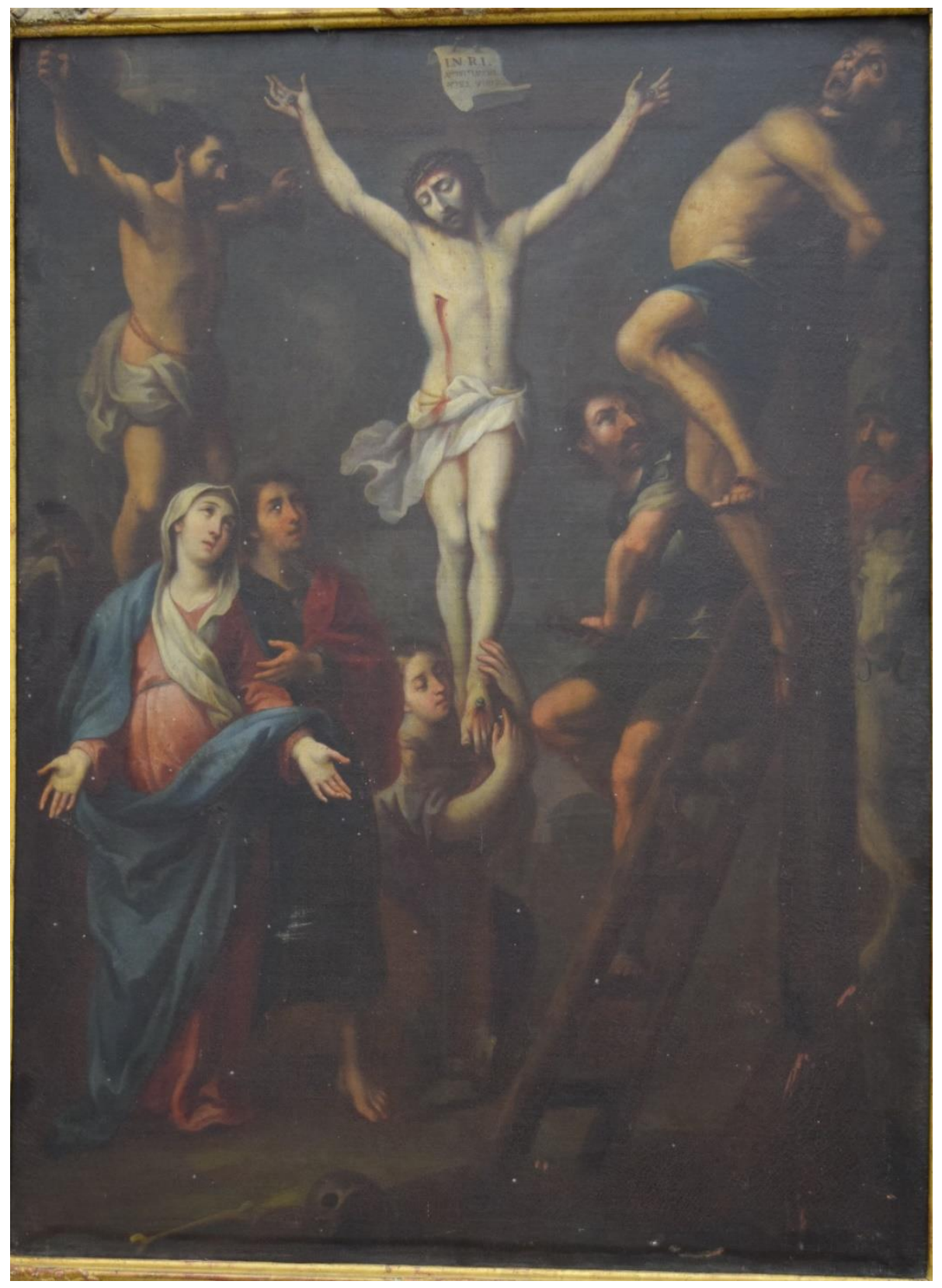

Fig. 3. José de Ibarra, Muerte de Cristo, 1744, Colección particular. OFotografía Alena Robin

En la primera mitad de la década de 1740, cuando se realizó la serie pasionaria objeto de este artículo, José de Ibarra tuvo una prolífica actividad. En su producción destacan obras y alusiones, sumamente importantes, para la Nueva España, como las tres pinturas en el Salón General de Actos de San Ildefonso que se estrenó el 22 de marzo de 1740.9 En marzo del siguiente año, Ibarra aparece como fiador de Gerónimo de Balbás para el altar mayor de la catedral metropolitana. Se menciona en un

\footnotetext{
${ }^{9}$ Mues Orts, El pintor novohispano José de Ibarra, vol. 3, Anexos documentales, pp. 12 y ss.
} 


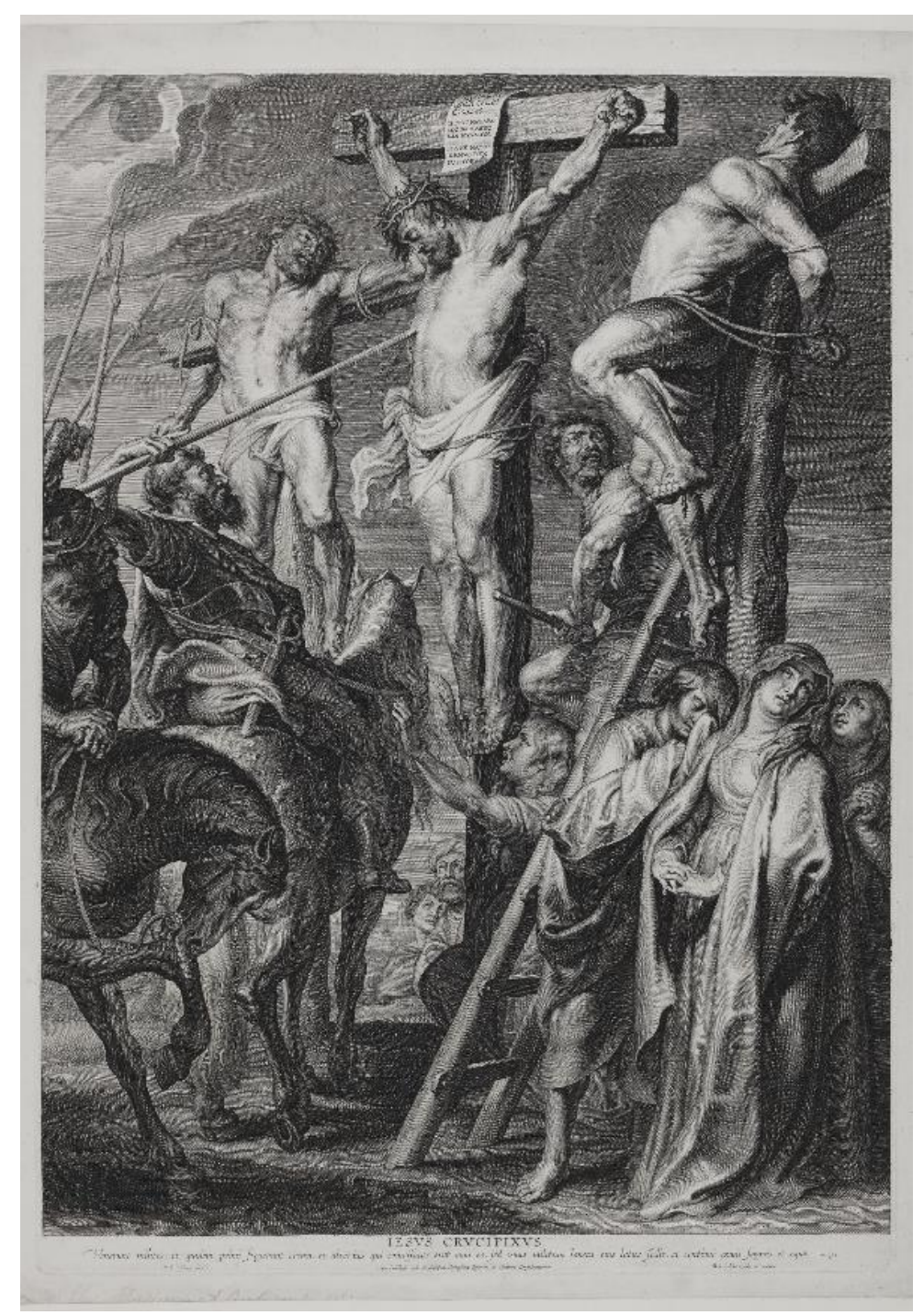

Fig. 4. Boetius á Bolswert siguiendo a Pedro Pablo Rubens, La lanzada, 1631, British Museum. () The Trustees of the British Museum. Shared under a (CC BY-NC-SA 4.0) licence

documento que la pintura de la bóveda fue realizada por Ibarra. En 1742, se discute en el cabildo el presupuesto de Ibarra y de Francisco Martínez para el dorado del retablo. En ese mismo año, Ibarra también fue responsable del diseño del arco triunfal de la entrada del Conde de Fuenclara. Nuevamente se toca el tema del dorado del altar mayor de la catedral en 1743 , en donde se menciona a Ibarra, aun cuando, desafortunadamente, Francisco Martínez ganó este concurso. También realizó varios retratos para las Galerías de Virreyes del Ayuntamiento y del Palacio.

Ibarra ideó varios lienzos de temática cristológica, en algunos casos de imágenes de devoción (como el Cristo de Santa Teresa, también conocido como el Cristo de Ixmiquilpan), y también pintó varios ciclos ilustrando los episodios de la Pasión de Cristo. Paula Mues atribuye a José de Ibarra el Vía 
Crucis de la iglesia de Santa María la Redonda en la Ciudad de México. ${ }^{10}$ Recientemente, también se ha reconocido como obra de su autoría el Vía Crucis de la catedral de Puebla, anteriormente atribuido a Miguel Cabrera. ${ }^{11}$ La serie pasionaria firmada por Ibarra, tema de la presente investigación, sigue siendo propiedad de los descendientes de Tomás Barbadillo.

\section{Tomás Barbadillo en Veracruz}

La tradición sostenida por la familia, hasta la fecha, defiende la teoría de que Tomás Barbadillo viajó hacia Nueva España como sacerdote, en donde amasó una fortuna considerable en Veracruz y varios familiares se reunieron con él para ayudar en la gestión de sus negocios. ${ }^{12}$ Testó en 1802 y el 24 de diciembre de 1808 se realizó el primer inventario de sus bienes, seguido de otros dos, en 1811 y 1813 que sumaron una cantidad de 28,755 pesos. ${ }^{13}$ En la liquidación de sus bienes se menciona una botica y cuatro casas que poseía. ${ }^{14}$ A su muerte, sus sobrinos se encargaron de sus bienes, y regresaron a España en la confusión de las guerras de Independencia de principios del siglo XIX.

De haber llegado a América como sacerdote, no es en el ámbito de la Iglesia en el que destacó Tomás Barbadillo, dado que documentos de archivos de la época localizados en la Ciudad de México y el puerto de Veracruz sitúan a Tomás Barbadillo dentro del mundo mercantil; en ningún momento se hace alusión a que se desarrollase como eclesiástico. En septiembre de 1796, se describe a Barbadillo como "vecino y del comercio de esta ciudad" de Veracruz, ubicando su casa "ocupada enteramente" y "recién fabricada" en la calle de santo Domingo con esquina de la Condesa. ${ }^{15}$ También aparece Tomás Barbadillo entre 1797 y 1801 como uno de los vocales de la mesa directiva de la Tercera Orden de san Francisco de Veracruz. ${ }^{16}$ Aquí vale la pena recordar que la Tercera Orden de san Francisco es una corporación de laicos

\footnotetext{
10 Mues Orts, El pintor novohispano José de Ibarra, vol. 4, Catálogo de la obra de José de Ibarra, 2.3, cat. 112-120.

${ }_{11}$ Mues Orts, "Sixth Station of the Cross" en Painted in Mexico, pp. 209-210.

12 Antonio P. Barbadillo, Historia de las bodegas Barbadillo, (Sanlúcar de Barrameda: Bodegas Barbadillo, 2001), pp. 27, 45.

${ }_{13}$ No se ha encontrado la partida de defunción de Tomás Barbadillo en las actas parroquiales de Veracruz porque los registros conservados están incompletos. Se encontró, en la parroquia de Nuestra Señora de la Asunción de Veracruz, en el libro de defunciones de 1800 a 1808, una referencia del 21 de enero de 1808, en donde aparece Barbadillo como albacea y heredero de Don Fernando González, lo que implica que Barbadillo murió con posterioridad a esta fecha. Family Search "México, Veracruz, registros parroquiales y diocesanos, 1590-1978", consultado el 22 de noviembre del 2017: https://familysearch.org/ark:/61903/3:1:3357-9P4Z-N87? CC =1883382\&wC=3P3T-

DPF\%3A177342901\%2C177342902\%2C178468501

14 Barbadillo, Historia de las bodegas Barbadillo, pp. 45-47.

15 Archivo Histórico de Veracruz, caja 53, vol. 61, fs. 75v-76v, y 297r-300r. Se trata de acuerdos del Cabildo sobre la necesidad de establecer un reconocimiento acerca del estado de deterioro de la casa de Tomás Barbadillo en el que se concluyó que el edificio no tenía defecto alguno y carecía de fundamento la voz que originó la noticia.

${ }^{16}$ Archivo Histórico de Veracruz, Fondo Tercera Orden de san Francisco (1727-1809), caja 1, vol. 1, fs. 4r y v, 359 bis, $361,362,377$ bis y $377 v, 382$. Se abordan las juntas de la tercera orden en las siguientes fechas: 11 de marzo de 1797, 1ero de noviembre de 1800, 11 de octubre de 1801 y 8 de noviembre de 1801. También hay copias de documentos, mandados al ayuntamiento por la Tercera Orden, en las siguientes fechas: 14 de septiembre 1800 y 14 de octubre del mismo año.
} 


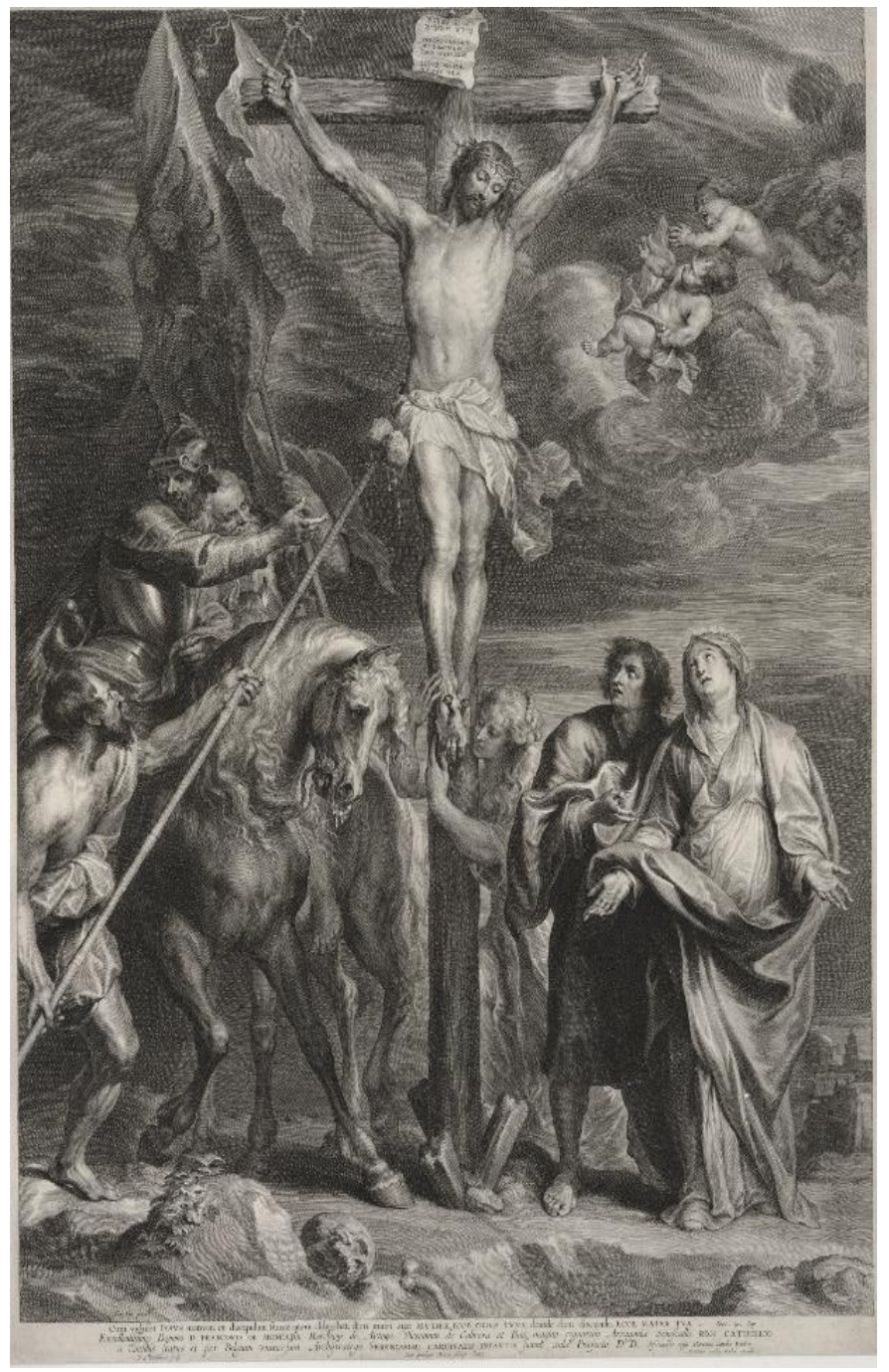

Fig. 5. Schelte á Bolswert siguiendo a Anton van Dyck, Cristo en la cruz, 1630-1635. British Museum. () The Trustees of the British Museum. Shared under a (CC BY-NC-SA 4.0) licence

que mantienen una relación estrecha con la orden seráfica. ${ }^{17}$ En la Ciudad de México, hacia finales del siglo XVII y principios del siglo XVIII, existió una vinculación interesante entre la tercera orden seráfica y la élite mercantil del momento, alrededor de la devoción del Vía Crucis de capillas. ${ }^{18}$ Por lo tanto no debe sorprender que Barbadillo, como importante comerciante en Veracruz, estuviese asociado con esta corporación religiosa de seglares.

Tomás Barbadillo aparece también mencionado en un pleito del Real Tribunal del Consulado de la Ciudad de México, como apoderado del fallecido

\footnotetext{
17 Juan B. Iguíniz, Breve historia de la Tercera Orden Franciscana en la Provincia del Santo Evangelio de México, desde sus orígenes hasta nuestros días, (Ciudad de México: Patria, 1951).

18 Alena Robin, Las capillas del Vía Crucis de la ciudad de México. Arte, patrocino y sacralización del espacio, (Ciudad de México: UNAM/ IIE, 2014).
} 
Juan Antonio de Uzelay, vecino y comerciante de Cádiz. ${ }^{19}$ El pleito es largo, dado que se extiende desde julio de 1789 hasta su resolución en mayo de 1792, pero lo importante es que siempre se menciona a Barbadillo como vecino de Veracruz y comerciante en ella.

Por otro lado, Barbadillo aparece como prestamista del capitán Don Francisco Luis Calderón, vecino de la Villa de Córdoba, por la suma de 2,200 pesos, préstamo que debía pagarse a finales de diciembre de $1782 .{ }^{20}$ En otra ocasión es Barbadillo quien aparece como acreedor por una cantidad de poco más de 1,000 pesos, por el importe de unos barriles de aguardiente, con el mismo capitán Francisco Luis Calderón. ${ }^{21}$ Barbadillo es mencionado como acreedor del capitán José Máximo Ruiz de Castañeda, en la ciudad de Guanajuato, por un montante de cerca de 90,000 pesos, deuda contraída en mayo de 1794. ${ }^{22}$ Nuevamente, en estos documentos se presenta a Tomás Barbadillo como "vecino y del comercio de la ciudad de Veracruz". También hay información de entrega de dinero de Querétaro hacia Veracruz, destinado a Tomás Barbadillo, por "concepto de trozos de paño" entre 1801 y $1804 .{ }^{23}$

De su actividad comercial, Matilde Souto Mantecón ha registrado que recibió las siguientes mercancías que llegaron a Veracruz, el 15 de noviembre 1804, procedentes de Cádiz: 100 pieles de tafiletes encarnados, 30 docenas de libros de oración mental, 36 ramilletes, cuatro juegos de la Galería de las mujeres fuertes, 40 catecismos, y textiles. ${ }^{24}$ El 3 de marzo de 1809 , en un bergantín que salía rumbo a La Habana, Manuel Martín de Barbadillo, su sobrino, remitió a instancias de Tomás Barbadillo 2,500 pesos de plata doble para que se invirtieran en azúcar en la isla para que posteriormente se enviasen a España. Para entonces, ya había fallecido Tomás, pero su sobrino actuó en su nombre. Por cuenta y riesgo de la casa de Tomás Barbadillo en Veracruz, se registraron 20 medios tercios de cera blanca que llegó a Veracruz el 30 de agosto de 1814, procedente de La Habana.

Veracruz fue la principal puerta de entrada de personas, ideas, y mercancías de la América española, desde el primer contacto entre Hernán Cortés y las poblaciones nativas. Desde entonces, Veracruz fue desarrollándose como ciudad de paso. "No se fabrica allí cosa alguna. Aquella ciudad es verdaderamente un lugar de tránsito."25 Con estas palabras, Antonio Ulloa, comandante de la flota de 1776 de origen sevillano, describe Veracruz. En su crónica detallada de la ciudad, destacó que no correspondía

\footnotetext{
${ }^{19}$ Archivo General de la Nación (AGN en adelante), Consulado, vol. 4, exp. 3, fs. 318-357.

${ }^{20}$ AGN, General de Parte, vol. 69, exp. 97, fs. 175v-176.

${ }^{21}$ AGN, General de Parte, vol. 69, exp. 206, fs. 273 r y v. El documento se emitió en la Ciudad de México el 3 de noviembre de 1785, pero alude a hechos anteriores.

22 A falta de cumplir los pagos, Ruiz de Castañeda, se vio en la obligación de hipotecar la hacienda de Santa Bárbara Calderón. AGN, General de Parte, vol. 76, exp. 284, fs. 205v-206. El pleito continuaba abierto todavía en agosto de 1804, cfr. AGN, General de Parte, vol. 79, exp. 247, fs. 222v-223v.

${ }^{23}$ AGN, Indiferente Virreinal, Caja 5547, exp. 60, (Industria y Comercio), fs. 1, 2, 4, 6.

${ }^{24}$ Matilde Souto Mantecón, Mar abierto. La política y el comercio del Consulado de Veracruz en el ocaso del sistema imperial, (Ciudad de México: El Colegio de México, Instituto de Investigaciones Dr. José María Luis Mora, 2001), p. 280. Lamentablemente, la autora no especifica la fuente de sus datos.

${ }^{25}$ Francisco de Solano, ed., Antonio Ulloa y la Nueva España, (Ciudad de México: UNAM, 1987), p. 28.
} 
el aspecto pobre de la localidad con las riquezas que pasaban por el puerto. Lo explica, en parte, por la ubicación penosa de su fundación, los fuertes vientos, el aire húmedo y salitroso, y los aguaceros copiosos, manifestando que: "Las iglesias son regulares, sin cosa particular."26 Menciona la existencia de una sola parroquia con dos capillas que le sirven de ayuda, alude a la presencia de los franciscanos, dominicos, mercedarios, y agustinos, destaca la presencia de tres hospitales, y subraya la ausencia de conventos de monjas o algún beaterio.

En la segunda mitad del siglo XVIII, los Decretos de comercio libre de 1765, 1778, y 1789 fueron modificando las reglas estrictas del comercio colonial, circunstancia que atrajo un nuevo grupo de españoles peninsulares a Veracruz. ${ }^{27}$ Este es el contexto en el que se enmarcan las actividades mercantiles de Tomás Barbadillo. La mayoría de los españoles que iban a Veracruz lo hacían con un propósito específico en mente: participar de las grandes posibilidades que ofrecía el lucrativo comercio entre las dos orillas del Atlántico. Muchos ya tenían algún pariente establecido en las actividades mercantiles en la ciudad portuaria; ${ }^{28}$ este sería el caso de los sobrinos que se reunieron con Tomás Barbadillo en América. Para algunos peninsulares, Veracruz era una ciudad de paso, pero otros se establecieron de manera definitiva en el puerto por la gran cantidad de negocios que llevaban ahí. Las actividades de los comerciantes en Veracruz se centraban alrededor del envío de plata que provenía de las minas de Zacatecas y Guanajuato; también eran importantes la cochinilla de Oaxaca, el algodón de Puebla, Tlaxcala y Querétaro, y el azúcar de la región de la costa. ${ }^{29}$ Aunque las alianzas matrimoniales con las hijas de las ricas familias de criollos (españoles nacidos en América) era otra manera de ascender en la escala social del virreinato, el análisis realizado por Jackie $\mathrm{R}$. Booker permite establecer que la mayoría de los comerciantes peninsulares en Veracruz eran solteros, una situación que también se presenta en otras áreas de la América española, como lo ha establecido David Brading en el área central de Nueva España, o Susan Socolow en Buenos Aires. ${ }^{30}$

Se desconoce cuándo y en qué circunstancias se produjo la adquisición de la serie pasionaria de Ibarra por parte de Tomás Barbadillo, aunque parece evidente que no se trató de un encargo directo del pintor. La serie está firmada y fechada en 1744, época en la que Barbadillo no había llegado aún a Nueva España. Se desconoce con exactitud la fecha en la que Barbadillo llegó a Veracruz, pero la tradición familiar mantiene que tal acontecimiento se produjo entre 1760 y 1770 y tal periodización hay que ponerla en relación con José de Ibarra quien falleció en 1756 . Se ignora en qué contexto se realizó

\footnotetext{
26 Solano, Antonio Ulloa y la Nueva España, p. 16.

27 Jackie R. Booker, "The Veracruz Merchant Community in Late Bourbon Mexico: A Preliminary Portrait,

1770-1810", The Americas, 45, 2, (1988), p. 189.

${ }^{28}$ Booker, "The Veracruz Merchant Community", pp. 189-190.

29 Booker, "The Veracruz Merchant Community", pp. 190-192.

${ }^{30}$ Booker, "The Veracruz Merchant Community", pp. 194, 196, 198.
} 
inicialmente el ciclo pasionario de Ibarra, es decir no se sabe si se produjo para su uso en Veracruz o en la Ciudad de México. Tampoco se conoce dónde se conservó la serie entre el momento de su realización por el pintor y el momento de adquisición por Barbadillo, ni el contexto en que se adquirió. Nada se sabe de los talleres de pintores en Veracruz y región colindante, pero sí se conocen datos acerca de pintores famosos que enviaban cuadros a la zona, aunque poco se ha conservado, en parte debido al clima muy húmedo de la costa. ${ }^{31}$

\section{La circulación de grabados europeos en Nueva España}

Esta sección aborda un aspecto transatlántico peculiar de la serie pasionaria de Ibarra: su relación con la circulación de grabados europeos en Nueva España. Fue común que los artistas europeos recurrieran a fuentes grabadas como inspiración de sus propias creaciones a lo largo de la Edad Moderna. ${ }^{32}$ No fue una práctica exclusiva de los pintores novohispanos, ni de José de Ibarra. No implica, tampoco, que los pintores trabajasen directamente con la fuente grabada dado que había estampas que resultaban tan populares, que el modelo quedaba asimilado como referencia visual en la tradición pictórica. Las pinturas de origen europeo también circularon en América, pero no con la misma extensión que las fuentes grabadas. La diseminación de modelos europeos en Nueva España ha sido ya objeto de análisis entre los especialistas. ${ }^{33}$ Los estudios en relación al uso de los grabados en Nueva España, y en general en Hispanoamérica, han puesto el énfasis en la identificación formal de las fuentes empleadas por los pintores. ${ }^{34}$

No obstante, se sabe poco en cuanto a la circulación de las estampas en Nueva España. Varios contratos aluden a algún "grabado" como una fuente que el mecenas recomienda que se emplee por un pintor para una obra en particular, pero pocas veces se identifica de qué estampa se trataba. Algunos inventarios de los bienes que se han conservado después del óbito de ciertas personas se mencionan "estampas", pero suelen ser tan escuetos en la información que la mayoría de las veces es imposible saber el tema, el autor, o el uso que se les daba. Además, se desconoce si en los talleres de artis-

\footnotetext{
31 Véase Jorge Alberto Manrique, "Una colección: un museo", Museo de arte del Estado de Veracruz, (Ciudad de México/ Veracruz: Fondo Cultural BANAMEX/ Gobierno del Estado de Veracruz, 2001), p. 25, y Juana Gutiérrez, "Veracruz colonial en el siglo XVIII," Museo de arte del Estado de Veracruz, (Ciudad de México/ Veracruz: Fondo Cultural BANAMEX/ Gobierno del Estado de Veracruz, 2001), pp. 39-44.

32 Véase, por ejemplo, Benito Navarrete Prieto, La pintura andaluza del siglo XVII y sus fuentes grabadas, (Madrid: Fundación de Apoyo a la Historia del Arte Hispánico, 1998).

33 Véase, por ejemplo, Clara Bargellini, "Difusión de modelos: grabados y pinturas flamencos e italianos en territorios americanos" en Pintura de los reinos. Identidades compartidas. Territorios del mundo hispánico, siglos XVI-XVIII, ed. Juana Gutiérrez Haces et al., (Ciudad de México: Fomento Cultural Banamex, 2009), vol. 3, pp. 965-1005; Helga Von Kügelgen, "La pintura de los reinos y Rubens" en Pintura de los reinos, vol. 3, pp. 1008-1078.

${ }^{34}$ En este sentido, Pessca (The Project for the Engraved Sources of Spanish Colonial Art) es un recurso fundamental. El proyecto ha identificado cerca de 5000 correspondencias entre obras coloniales y fuentes grabadas europeas, cifra que seguirá creciendo. Cfr. Almerindo Ojeda, "The Project for the Engraved Sources of Spanish Colonial Art", 2005-present, www.colonialart.org
} 


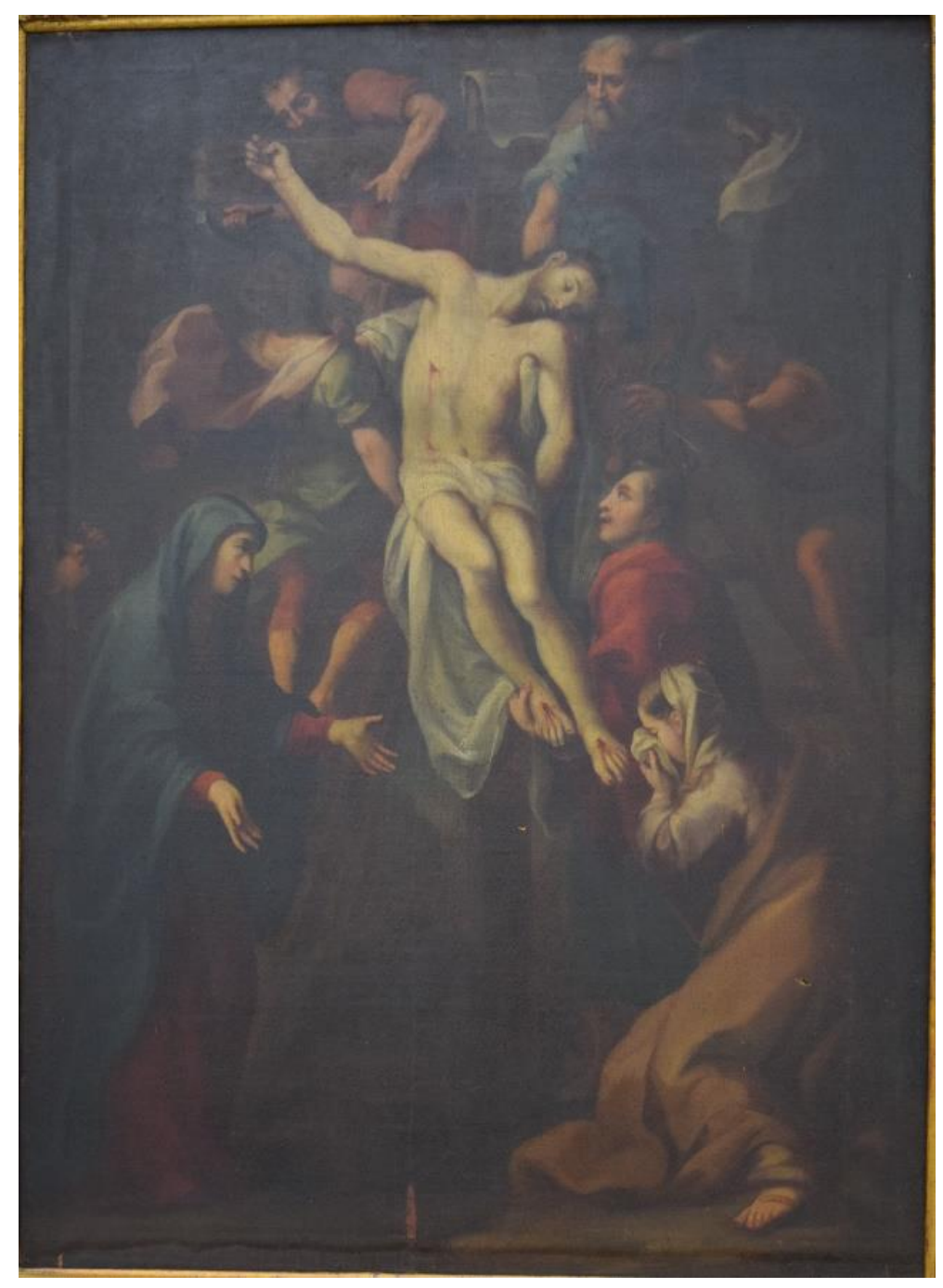

Fig. 6. José de Ibarra, Descendimiento de la Cruz, 1744. Colección particular. @Fotogragía Alena Robin

tas se prestaban las colecciones de grabados entre ellos o si se heredaban dentro de las dinastías de pintores. Muchos grabados circularon formando parte de los de libros ilustrados como sucedió con las imágenes de Evangelicae historiae imagines de Jerónimo Nadal (1507-1580) o las ilustraciones Iconum Biblicarum, con grabados de Matthaus Merian (15931650). ${ }^{35}$

\footnotetext{
35 Véase por ejemplo: Alena Robin, "El retablo de Xaltocán, las Imágenes de Jerónimo Nadal y la Monja de Ágreda", Anales del Instituto de Investigaciones Estéticas, XXVIII, 88, (2006), pp. 53-70.; Marcela Corvera Poiré, Elisa Ortiz Hernández, "Matthaus Merian y Antonio Tempesta en la Nueva España" en Amans artis, amans veritatis, Coloquio internacional de arte e historia en memoria de Juana Gutiérrez Haces, ed. Gustavo Curiel, (Ciudad de México: UNAM/ IIE/ Facultad de Filosofía y Letras/ Fomento Cultural BANAMEX, 2011) pp. 289-307 y Jaime Cuadriello, "Una Biblia para el Nuevo Mundo: La Conquista de México y los
} 
Por el momento, solo se conoce un pequeño corpus de estampas sueltas, de procedencia europea, que ha sobrevivido de la época colonial. Por ejemplo, se conoce la existencia de dos álbumes de grabados en la Ciudad de México que ofrecen una colección ecléctica de grabados. Uno de ellos se custodia en la Biblioteca Nacional de México y está constituido por 123 estampas, principalmente de origen italiano. Clara Bargellini ha estudiado este álbum con un grupo multidisciplinario de especialistas y han llegado a la conclusión de que, lo más probable, fuese ensamblado alrededor de $1700 .{ }^{36}$ Por diferentes razones, la colección se asocia con el colegio jesuita de San Pedro y San Pablo de la Ciudad de México. Se determinó, a través de un examen minucioso de la materialidad de la colección, que los grabados tuvieron una vida previa antes de conformar el muestrario: algunas de las estampas presentan marcas, anotaciones, códigos de color que especificase dónde recurrir a qué tono, etc. El segundo álbum, constituido por 298 grabados, se conserva en la biblioteca del Museo Nacional de Antropología de la Ciudad de México. ${ }^{37}$ Se considera que fue creado a principios del siglo XIX, cuando la biblioteca fue fundada. Como en el caso del primer álbum, los grabados que lo conforman demuestran marcas probables de uso por parte de un pintor: algunos grabados han sido marcados con una cuadrícula, una técnica común para transferir una composición a mayores dimensiones, probablemente siendo sujetadas a algún soporte, como parecen sugerir las huellas en las esquinas superiores. Estos testimonios ofrecen una vista bastante completa de las posibles estampas europeas que circularon en Nueva España.

Se espera que futuras investigaciones proporcionen más información sobre la distribución y diseminación de fuentes grabadas en talleres novohispanos. No obstante, la evidencia subsiste: los pintores novohispanos, citan, de diferentes maneras y en varios grados, fuentes europeas no a través de sus originales, sino a partir de su circulación en grabados.

\section{La serie pasionaria de Ibarra y sus fuentes grabadas}

La serie de la familia Barbadillo está conformada por quince lienzos que ilustran los siguientes pasajes de la Pasión de Cristo: 1) Lavatorio de los pies; 2) Institución de la eucaristía; 3) Oración en el huerto; 4) Prendimiento; 5) Jesús ante Caifás; 6) Jesús escarnecido; 7) Flagelación; 8) Coronación de espinas; 9) Ecce Homo; 10) Cristo cargando la cruz; 11) El despojo; 12) Muerte de Cristo; 13) Descendimiento de la cruz; 14) Piedad;

emblemas políticos de Mattäeus Merian" en Florilegio de Estudios de Emblemáticas. Actas del VI Congreso Internacional de Emblemática/ The Society for Emblem Studies, ed. Sagrario López Poza, (La Coruña: Sociedad de Cultura Valle Inclán, 2004), pp. 33-48.

${ }^{36}$ Clara Bargellini et al., "Un álbum de grabados antiguos del Fondo Reservado de la Biblioteca Nacional de México" En Memorias del Congreso Internacional: Las edades del libro, ed. Marina Garone Gravier, et al., (Ciudad de México: UNAM, 2016), pp. 355-392.

${ }_{37}$ Aaron M. Hyman, "Patterns of Colonial Transfer. An Album of Prints in Mexico City" Print Quarterly, XXXIV, 4, (2017), pp. 393-399. 


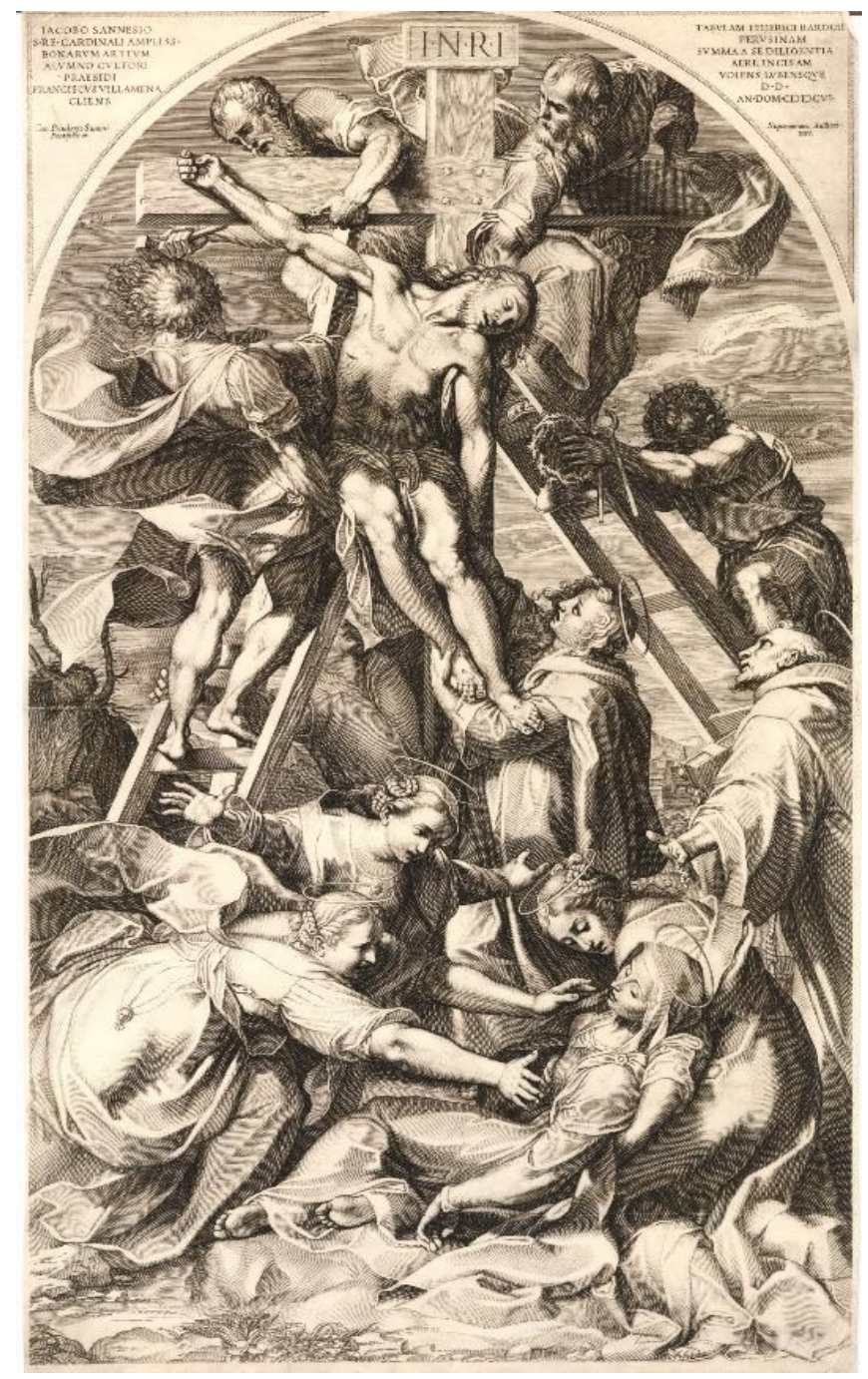

Fig. 7. Francesco Villamena siguiendo a Federico Barocci, Descendimiento de la Cruz, 1606, grabado. British Museum. (C) The Trustees of the British Museum. Shared under a (CC BY-NC-SA 4.0) licence

15) Entierro de Cristo. ${ }^{38} \mathrm{~A}$ día de hoy, no se ha encontrado un contrato $u$ otro documento histórico que registre el contexto en el que se encargó la serie pasionaria que nos ocupa. Las obras nunca han sido expuestas al público en tiempos recientes. Tampoco han sido mencionadas por los estudios de pintura novohispana, ni formaban parte del catálogo de obras conocidas de José de Ibarra.

Es importante señalar que la serie de Ibarra incorpora el legado de la tradición pictórica del virreinato y dialoga con otras imágenes pasionarias

\footnotetext{
38 Me fue imposible ver los cuadros del Prendimiento y la Piedad de esta serie, que son propiedad de otra rama de la familia. Los lienzos miden alrededor de $113 \times 84 \mathrm{~cm}$. Las pinturas han sido reenteladas, posiblemente a su llegada a España. Agradezco esta información a Consuelo Olaguibel.
} 
novohispanas. Por la temática de las dos primeras escenas, Lavatorio de los pies y la Institución de la eucaristía, se descarta la posibilidad de que se trate de un Vía Crucis, pues este ejercicio piadoso empieza, regularmente, por la condena a muerte de Jesús por Pilatos. ${ }^{39}$ Faltan, además, varias estaciones, normalmente asociadas con esta devoción, como son las tres caídas, La Verónica, Las Mujeres piadosas, entre otras escenas. Por ello, aun cuando el número de cuadros de la serie podría sugerir la devoción de un Vía Crucis, pues se acerca a las 14 estaciones de esta devoción franciscana, lo más probable es que se trate de otro ejercicio pasionario, que presta más énfasis a los momentos previos a la sentencia de Jesús.

Diez escenas, de las quince que constituyen la serie pasionaria de Ibarra, provienen de fuentes grabadas que no siempre fueron fáciles de encontrar, pero una vez identificadas fue sumamente fácil emparejarlas por su obvio parecido. Las evidencias del ciclo sugieren que también habría una estampa detrás de las cinco composiciones remanentes, pero aún no se han cotejado debidamente con las fuentes. En vez de ofrecer una asociación lineal entre los cuadros y las fuentes empleadas, se presenta más bien la identificación de diferentes tipos de apropiación por parte de José de Ibarra para ofrecer una reflexión más profunda sobre este fenómeno.

En ciertas ocasiones, Ibarra se inspiró solamente en una estampa para la composición de un cuadro, como se puede apreciar en este lienzo de Cristo ante Caifás (113 x $84 \mathrm{~cm}$. aprox.) (Fig. 1). Aquí el pintor novohispano está citando, casi directamente, un grabado del flamenco Marinus Robyn van der Goes (1599-1639) (Fig. 2), basado en una pintura del mismo tema del también flamenco Jacob Jordaens (1593-1678). La postura de los personajes, la tarima, el perro, la ambientación arquitectónica son elementos que Ibarra tomó prestados del grabado. No obstante, el pintor novohispano simplificó, respecto al original, la balaustrada del fondo y la muchedumbre que acompaña a Jesús con el objetivo, probablemente, de incrementar la claridad visual de la composición.

En otros casos, Ibarra usó una combinación de estampas que dispuso de una manera creativa, como en la representación de la Muerte de Cristo ( 113 x $84 \mathrm{~cm}$.) (Fig. 3). Las dos estampas revisadas aluden, de forma específica, al episodio de la lanzada, pero el centurión desaparece en la composición de Ibarra y solo se representa el desenlace de la acción. El primer grabado (Fig. 4), de Boetius à Bolswert (c. 1585-1633), proviene de una composición de Pedro Pablo Rubens (1577-1640) y corresponde, en el cuadro de Ibarra, principalmente al grupo de la figura del mal ladrón de la derecha y el soldado en la escalera. El segundo grabado (Fig. 5), de Schelte à Bolswert (15861659), está basado en una obra del pintor flamenco Anton Van Dyck (1599-

39 Alena Robin, "Vía Crucis y series pasionarias en los virreinatos latinoamericanos", Goya, 339, (2012), pp. $130-145$. 


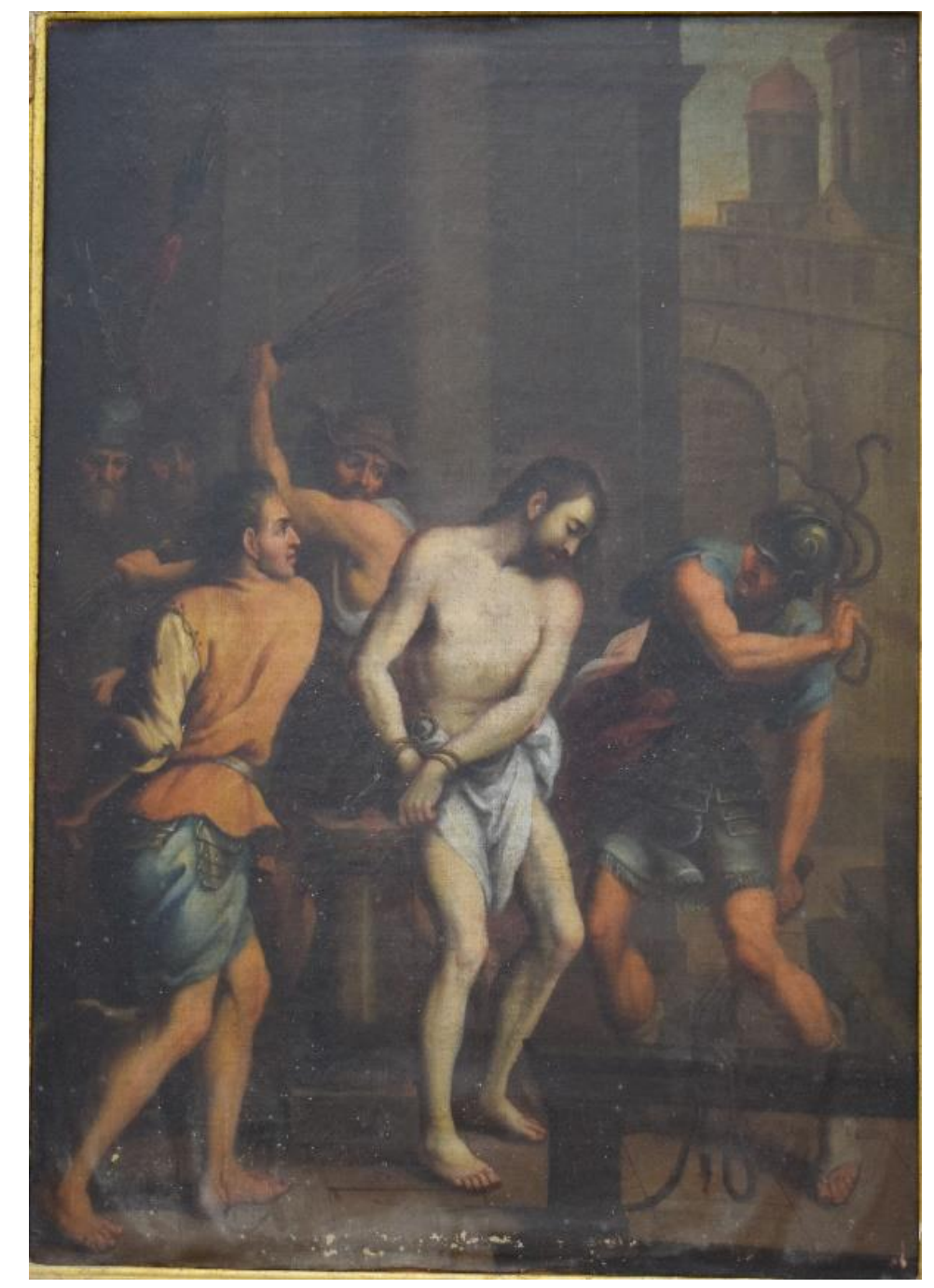

Fig. 8. José de Ibarra, Flagelación, 1744. Colección particular. OFotografía Alena Robin

1641). De la segunda composición se incorporaron las figuras de la Virgen, san Juan, la postura frontal de Cristo mientras pende de la cruz, la cartela de la parte superior y la calavera situada a los pies.

En la mayoría de los casos, Ibarra siguió de cerca el modelo al cual se refería, pero en ciertas ocasiones realizó alteraciones significativas, como en el caso de su composición del Descendimiento de la Cruz $(113 \times 84 \mathrm{~cm}$. aprox.) (Fig. 6). En este lienzo, Ibarra miró hacia Italia, y encontró la inspiración en el grabado de Francesco Villamena (1564-1624) de la composición de este tema (Fig. 7) ideada por Federico Barocci (1535-1612) para la catedral de San Lorenzo en Perugia. El cambio más importante que Ibarra introdujo es en relación con el grupo a los pies de la cruz. Es sumamente interesante encontrar a la Virgen, firme y erguida, en vez de desmayada, como en la composición italiana. Esta actitud concuerda más 
con el lenguaje plástico de la Contrarreforma, el cual impactó en gran medida la tradición pictórica novohispana. La actitud de la Virgen de Ibarra se acerca más a la versión de Rubens del tema, un modelo que circuló ampliamente en la América virreinal. También la cartela de la cruz de Ibarra, en donde se encuentra el título que se le puso a Jesús como rey de los judíos, es más compleja que la empleada en la composición de Barocci y más bien se relaciona con las estampas utilizadas por Ibarra en la escena de la Muerte de Jesús, en donde se encuentran las escrituras en varios idiomas, algo que Rubens formalizó, como se puede ver, por ejemplo, en la escena de La lanzada (Fig. 4).

Ibarra fue un pintor muy solicitado durante su época, que llegó a trabajar en múltiples proyectos al mismo tiempo. Cabe preguntarse si la constante demanda de obra podría ser una probable explicación al por qué seguir tanto y tan de cerca las estampas para su ciclo pictórico: quizás estaba demasiado ocupado para concebir nuevas imágenes de la Pasión. Por otro lado, el mecenas del proyecto podría haber señalado las fuentes. Se acepta, sin embargo, que José de Ibarra era un pintor culto, por lo tanto, esta apropiación de las fuentes grabadas por parte del maestro novohispano no fue ingenua ni pasiva: él sabía muy bien lo que hacía. Mientras realizaba su ciclo pasionario, más que copiar las composiciones de otros, estaba citando de ellos con un propósito muy claro. ${ }^{40}$

La serie pasionaria de José de Ibarra emplea una gran diversidad de fuentes grabadas para sus composiciones. Algunas de estas imágenes tuvieron diferentes versiones grabadas y tal coyuntura abre la interrogante acerca de cuál de estas versiones fue utilizada por Ibarra, teniendo en cuenta también que existe un importante desfase temporal entre la fecha de ideación del grabado y su apropiación por parte del pintor novohispano. En general, conviene resaltar el uso del artista de estampas flamencas, derivadas de composiciones de pintores del mismo origen, por ejemplo, de Pedro Pablo Rubens (Cristo cargando la cruz), Anton Van Dyck (Piedad), Jacob Jordaens (Fig. 1), Abraham van Diepenbeek (Fig. 8 y Coronación), y una composición flamenca atribuida a Frans Francken II (Ecce Homo). También hay dos escenas que provienen del italiano Federico Barocci (Fig. 6 y Entierro de Cristo). Estos pintores estuvieron, de una manera u otra, relacionados con Pedro Pablo Rubens: Anton Van Dyck y Abraham van Diepeenbeeck fueron discípulos o asistentes de Rubens en algún momento de su carrera; Jacob Jordaens y Rubens tuvieron el mismo maestro: Adam van Noort; Barocci y su pintura influyeron en Rubens. Varios de los grabadores responsables de las fuentes utilizadas por Ibarra también formaron parte del círculo personal

\footnotetext{
${ }^{40}$ Fueron importantes las siguientes fuentes para mi reflexión: Hans. J. Van Miegroet, "Copies-fantômes et culture de l'imitation au début de l'époque moderne en Europe" En L'estampe un art multiple à la portée de tous? Sophie Raux, Nicolas Surlapierre, Dominique Tonneau-Ryckelynck, eds., (Villeneuve d'Ascq: Presses Universitaires du Septentrion, 2008), pp. 47-64; Bargellini, "Difusión de modelos", pp. 990-991, 1000-1005; y Aaron M. Hyman, "Inventing Painting: Cristóbal de Villalpando, Juan Correa, and New Spain's Transatlantic Canon", The Art Bulletin, 99, 2, (2017), pp. 102-135.
} 


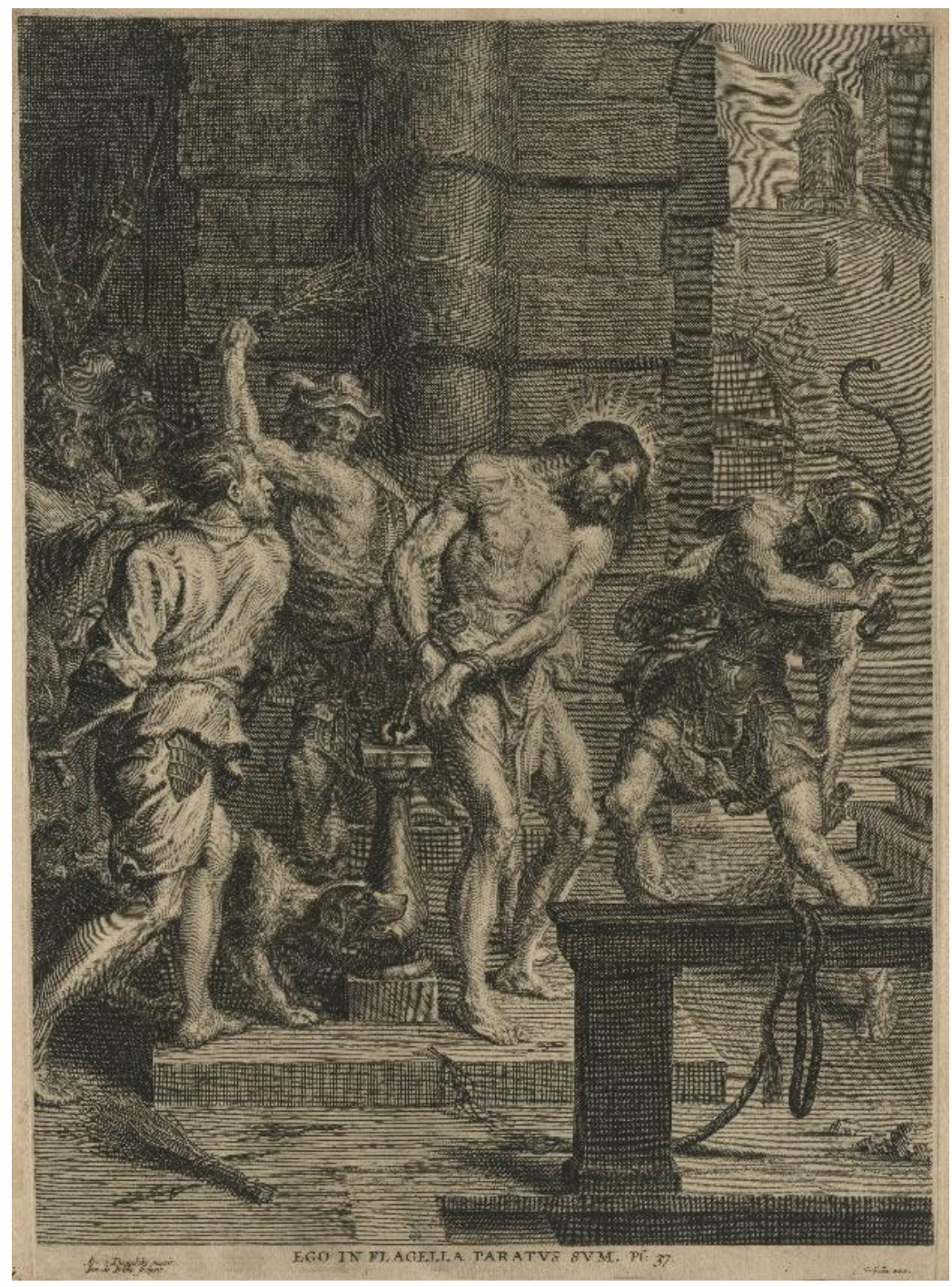

Fig. 9. Pieter de Bailliu siguiendo a Abraham van Diepenbeek Flagelación, s.f., grabado,. Musée Wittert, Collections artistiques de l’Université de Liège. OFotografía Université de Liège - Musée Wittert

de Rubens. Mucho ya se ha escrito sobre la importancia de Rubens en el arte colonial de Hispanoamérica. ${ }^{41} \mathrm{Su}$ influencia ha sido fundamental en general para la cultura visual virreinal y, en particular, con las imágenes pasionarias. Héctor Schenone afirmó que cada región de Hispanoamérica tenía su representación del Descendimiento de la cruz que "copia", parcial o totalmente, ya sea en pintura o en escultura, un grabado de la tabla que realizó Rubens para la catedral de Amberes. ${ }^{42}$ Sin embargo, en el caso de la serie pasionaria de Ibarra, es interesante apuntar la variedad de las fuentes

\footnotetext{
${ }^{41}$ Una importante compilación del impacto de los grabados derivados de las composiciones de Rubens en Von Kügelgen, "La pintura de los reinos y Rubens", pp. 1008-1078.

42 Héctor Schenone, Iconografía del arte colonial. Jesucristo, (Buenos Aires: Fundaciones Tarea, 1998), p. 336.
} 
a las que recurrió, tanto por el número de grabados, como de las pinturas de las cuales las propias estampas se derivaron.

La amplitud de las fuentes que se pueden rastrear en la serie pasionaria de Ibarra aluden, esencialmente, a la abundancia de material visual europeo que circulaba en la Ciudad de México y que estaba al alcance del pintor novohispano. En este caso preciso, se ignora si recurrió a estas fuentes grabadas atendiendo a una petición expresa del mecenas, cuyo nombre también se desconoce, o bien, si se valió del material que tenía a su disposición en el taller. Lo importante es que Ibarra pudo acceder a ellas y en este sentido, las evidencias visuales son un hecho.

Los grabados eran una herramienta de trabajo para los pintores: comunicaban ideas y modelos sobre los cuales podían desarrollar sus temas. Ibarra, no intentó, de ninguna manera, esconder las fuentes empleadas, más bien, al contrario. En algunos casos su apropiación de la estampa consultada fue casi literal mientras que, en otros casos, actuó de forma más ágil para disponer sobre sus lienzos la combinación de varias estampas. Resulta interesante, no obstante, que José de Ibarra no está tratando de innovar en su serie Pasionaria, como otros pintores contemporáneos a él lo hicieron, inspirándose, por ejemplo, en la literatura mística de la época. ${ }^{43}$ Ibarra reproduce, en la serie que nos interesa aquí, una iconografía ya aceptada y con una circulación amplia, en donde el decoro y la representación de los acontecimientos no se cuestionan, participando en un lenguaje globalizado propio de la Contrarreforma. Como lo comenta Aaron M. Hyman, al recurrir a los grabados europeos Ibarra, como otros pintores novohispanos, se posiciona a sí mismo dentro del canon transatlántico. ${ }^{44}$

El ciclo está firmado en diferentes lienzos, en diversos lugares. Algunas firmas son muy obvias, mientras que otras son difícilmente perceptibles y apenas legibles. Posiblemente, algunos de los cuadros en los que ya no se perciben mostraron, en algún momento, una firma que, por razones de conservación, ya no se aprecian. Según las ordenanzas del gremio de los

\footnotetext{
43 El propio Ibarra, en su serie de 1732, realizada para el claustro de religiosos betlemitas recurrió a la los escritos de la Monja de Ágreda, según como fue celebrada por la prensa de la época: "la Pasión del Señor, historiada, según la V. Agreda, en corpulentos Lienços del valiente Pinzel del Celebre Ybarra, ceñidos de admirables marcos, tallados, y dorados con todo esmero." Gazeta de México, 28 de diciembre de 1732, reproducido en: ed. Francisco González de Cossio, Gacetas de México. vol. 2, (Ciudad de México: Secretaría de Educación Pública, 1950), p. 75.

Otros ejemplos serían la serie de Gabriel de Ovalle o la de Ignacio Berbén, ambas conservadas en el convento de hermanos franciscanos de Guadalupe en Zacatecas. En el caso de Gabriel de Ovalle, el pintor propone unas iconografías muy atípicas de varias escenas pasionarias y, por ello, Clara Bargellini ha demostrado que el pintor estaba ilustrando los acontecimientos siguiendo el relato de las visiones de la Monja de Ágreda, tal como se describen en su obra, La mística ciudad de Dios. Véase Clara Bargellini, "Amoroso horror'": arte y culto en la serie de la Pasión de Gabriel de Ovalle de Guadalupe, Zacatecas" en Arte y violencia, ed. Arturo Pascual Soto, (Ciudad de México: UNAM/ IIE, 1995), pp. 499-524. Varias escenas de la serie de Ignacio Berbén se alejan también de las resoluciones aceptadas. Cfr. Maricela Valverde Ramírez, Ignacio Berben, un pintor del Reino de la Nueva Galicia, siglo XVIII, (Zacatecas: Universidad Autónoma de Zacatecas/ Gobierno del Estado de Zacatecas, 2009), pp. 85-132.

${ }^{44}$ Hyman, "Inventing painting..." pp. 102-135.
} 
pintores, sus miembros debían firmar las obras antes de poder vender o instalarlas. La motivación era principalmente económica, para poder identificar el autor de las pinturas, asegurando la calidad de las mismas, y sanciones para los que desarrollaban su actividad fuera de las ordenanzas. ${ }^{45}$ Lo usual en la pintura novohispana es que cuando se trata de una serie, el pintor firmaba sólo una vez, en uno de los cuadros, aunque hay algunos ejemplos donde se firmaron más de uno de los lienzos de la serie. ${ }^{46}$

La escena de Ibarra del Lavatorio de los pies exhibe dos firmas del pintor, lo cual no deja de llamar la atención. La firma más completa se encuentra hacia el lado izquierdo del cuadro, debajo del escalón en donde Jesús se dispone a lavar humildemente los pies a uno de sus discípulos. En este caso, la firma reza: "Josephus ab Ibarra fac. ${ }^{\mathrm{t}}$ anno Dni 1744", mientras que en uno de los escalones aparece una firma más corta, "Ibarra fac. ${ }^{t} . "$ Con su firma, Ibarra les está agregando su propio valor en el contexto novohispano. El pintor novohispano firma, sin embargo, "Ibarra facit"; no está declarando que inventó las composiciones, sino que hacía los cuadros.

Ibarra firmó, a veces de manera muy elaborada y en lugares estratégicos, para contextualizarse a sí mismo en relación a la tradición de los grandes maestros de la Contrarreforma. Al recurrir tanto, y de manera tan obvia, a fuentes grabadas, Ibarra está haciendo un homenaje a importantes pintores flamencos e italianos al citar sus creaciones: está demostrando su conocimiento de estos autores y sus creaciones originales. Ibarra ofrece, por tanto, una colección de imágenes pasionarias de "originales inaccesibles", compartiendo "el reconocimiento de la marca". ${ }^{47}$ De este modo, Ibarra manifestó que tenía en sus manos un material muy codiciado por el gremio de pintores novohispanos dado que los grabados a los que, implícita y explícitamente se aluden, evidencian que estaba familiarizado con los prototipos originales.

\section{Una serie pasionaria en la iglesia de La Profesa}

Mi primer acercamiento de la serie de Ibarra se produjo a través de material fotográfico digital que me fue enviado por lo actuales propietarios. Cuando vi las fotos, sabía que nunca había visto estos cuadros, no obstante, me resultaban muy familiares. Tal circunstancia se explica porque en la sacristía

\footnotetext{
45 Susan Deans-Smith, "'This Noble and Illustrious Art: Painters and the Politics of Guild Reform in Early Modern Mexico City, 1674-1768" En Mexican Sounding. Essays in Honour of David A. Brading, eds. Susan Deans-Smith y Eric Van Young, (London: Institute for the Study of the Americas, 2007), pp. 67-98.

${ }^{46}$ En el caso estudiado aquí, habría que hacer análisis más profundos para determinar si todas las firmas son originales, si alguna ha sido reforzada o repintada, todo lo cual es bastante habitual. Sobre la manera y el significado de firmar de los pintores novohispanos, véase Clara Bargellini, "Consideraciones acerca de las firmas de los pintores novohispanos" en El proceso creativo, ed. Alberto Dallal, (Ciudad de México, UNAM/ IIE, 2006), pp. 203-222; Clara Bargellini, "El artista 'inventor' novohispano" en Nombrar y explicar: La terminología en el estudio del arte ibérico y latinoamericano, ed. Patricia Díaz cayeros et al., (Ciudad de México, UNAM/ IIE, 2012), pp. 121-138.

${ }^{47}$ Estas expresiones provienen de Van Miegroet, "Copies-fantômes et culture de l'imitation", pp. 57-58.
} 


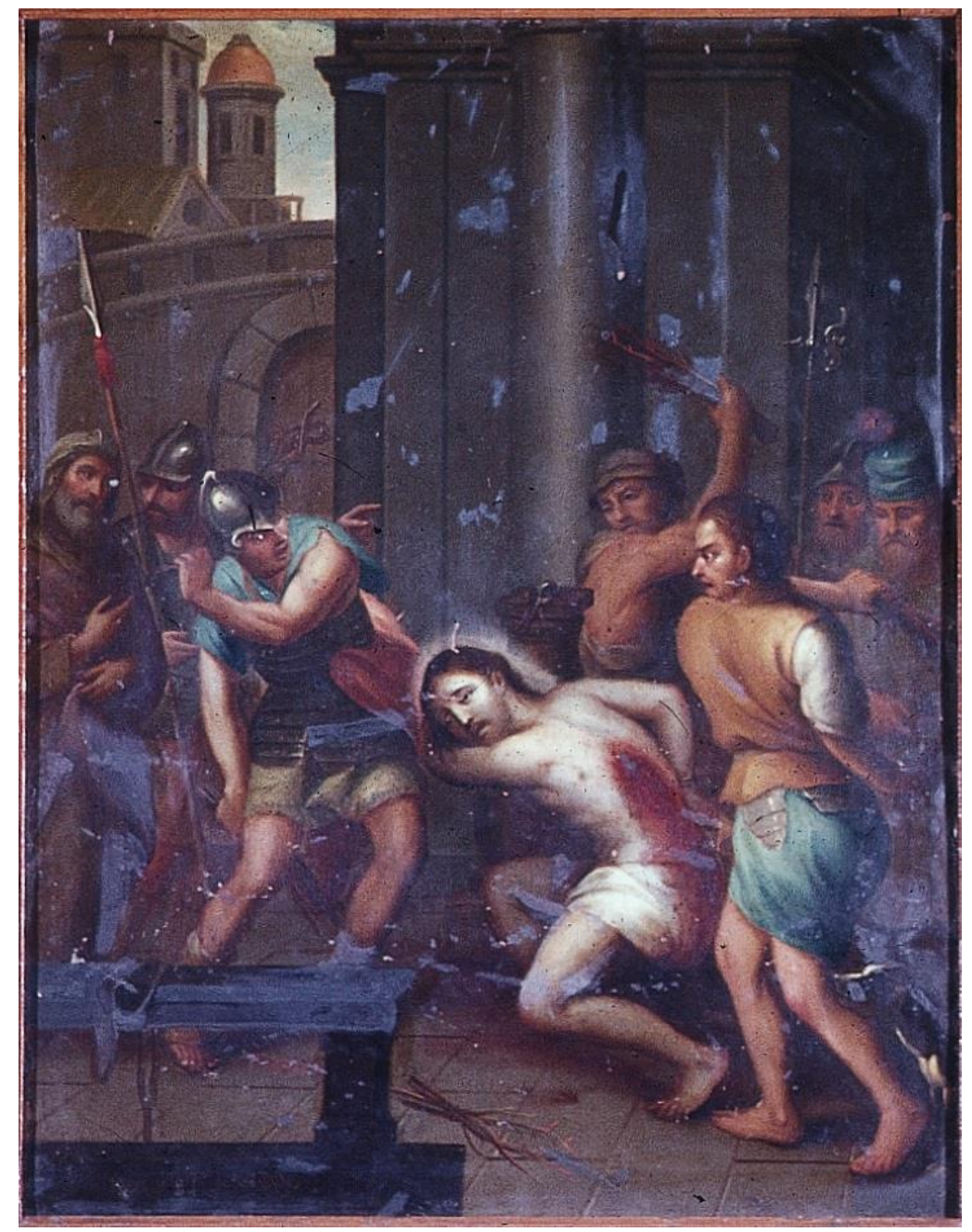

Fig. 10. José de Alcíbar, atribuido, Flagelación. La Profesa, Ciudad de México, Sacritía. @ Fotógrafo Rafael Rivera. Archivo Fotográfico "Manuel Toussaint”, Instituto de Investigaciones Estéticas, UNAM. (Reproducción autorizada por el Instituto Nacional de Antropología e Historia)

del templo de La Profesa de la Ciudad de México se conserva un ciclo pictórico de doce escenas que, para este artículo, he confrontado con la serie pasionaria inédita de Ibarra (Figs. 10-12). ${ }^{48}$ La serie del templo de la Profesa ha sido atribuida al pintor José de Alcíbar (act. 1751-1803), un pintor posterior a Ibarra pero con quien, seguramente, coincidió en algunos momentos. ${ }^{49}$ Once de las doce escenas que constituyen el ciclo de la Profesa

48 Los cuadros tienen unas dimensiones de $63 \times 49 \mathrm{~cm}$ en promedio. Las temáticas ilustradas son las siguientes: 1) Lavatorio de los pies; 2) Oración en el huerto; 3) Prendimiento; 4) Jesús escarnecido; 5) Flagelación; 6) Coronación de espinas; 7) Ecce Homo; 8) Cristo cargando la cruz; 9) El despojo; 10) Muerte de Cristo; 11) Descendimiento de la cruz; 12) La Piedad. Sólo la escena de la Piedad difiere, totalmente, de la serie de la familia Barbadillo. La serie está actualmente resguardada debido a los daños que la iglesia sufrió con el terremoto del 19 de septiembre del 2017. Por ello, si bien he visto la serie hace varios años para una anterior investigación, me ha sido imposible volver a estudiar la serie detenidamente con una mirada comparativa hacia la de Ibarra.

${ }^{49}$ Alena Robin, "La Pasión de Cristo según José de Alcíbar (Museo de Arte Sacro, Chihuahua, México)", Via Spiritus, Revista de História da Espiritualidade e do Sentimento Religioso, 17, (2010), p. 212. Algunos autores mantienen que Alcíbar fue discípulo de Ibarra, asunto que fue recientemente descartado por Karina 
son muy similares a las de la serie pasionaria de José de Ibarra, no sólo en su planteamiento, sino también en su colorido.

La disposición análoga de las escenas se podría explicar a través del manejo de las mismas fuentes grabadas, aunque hay algunos detalles que difieren. Por ejemplo, la postura del cuerpo de Cristo en la escena de la Flagelación es visiblemente diferente en ambas escenas, aun cuando el planteamiento del resto de la composición es análogo, pero con una disposición inversa (Figs. 8-10). El ambiente arquitectónico en el que tiene lugar la escena, además, proviene del mismo grabado. Lo mismo podría decirse de la Muerte de Cristo (Figs. 3-5, 11) y del Descendimiento de la cruz (Figs. 6-7, 12).

Explicar la similitud del colorido en ambas series es más complicado. Si bien algunas escenas de la Pasión presentan una serie de colores que solían estar codificados, por ejemplo, la capa roja en la Coronación de espinas o la túnica azul de la Virgen, no todos los colores estaban codificados. Por ejemplo, no toda la vestimenta de los apóstoles era predeterminada. Mencioné previamente el uso de códigos de color en algunos grabados en colecciones mexicanas que datan de la colonia, lo que podría explicar el uso de los mismos tonos en los dos ciclos pictóricos. Esta situación invita a preguntarse si estas series se habrán originado en el mismo taller de pintura y en el mismo periodo, utilizando idénticos repertorios de grabados y colores, circunstancia que explicaría las similitudes generalizadas entre ambas series. No deja de llamar la atención que dos series pictóricas usen los mismos grabados, lo cual puede indicar que los modelos fueron lo suficientemente populares para repetirse en dos ocasiones.

No resulta clara la filiación entre ambas series, pero al darse a conocer la serie de José de Ibarra, se puede replantear el estudio del ciclo del templo de La Profesa desde nuevas perspectivas, y cuestionar, nuevamente, los patrones de comunicación e intercambio en el temprano mundo globalizado.

\section{Consideraciones finales}

La serie pasionaria de José de Ibarra emplea una amplia diversidad de fuentes para sus composiciones. En este artículo se pone de manifiesto que utilizó en su producción pictórica religiosa fuentes flamencas e italianas. Sin embargo, precedentes contribuciones habían señalado la influencia francesa que Ibarra recibió a través de su conocimiento de los grabados de Charles Lebrun (1619-1690) de su Méthode pour apprendre à dessiner les passions (1698, primera edición póstuma). ${ }^{50}$

Lisette Flores García, El quehacer artístico-social de pintor novohispano: José de Alzíbar, (tesis doctoral). Escuela Nacional de Antropología e Historia, Ciudad de México, 2013, pp. 16-20.

50 Mues Orts, El pintor novohispano José de Ibarra, cap. 5. 


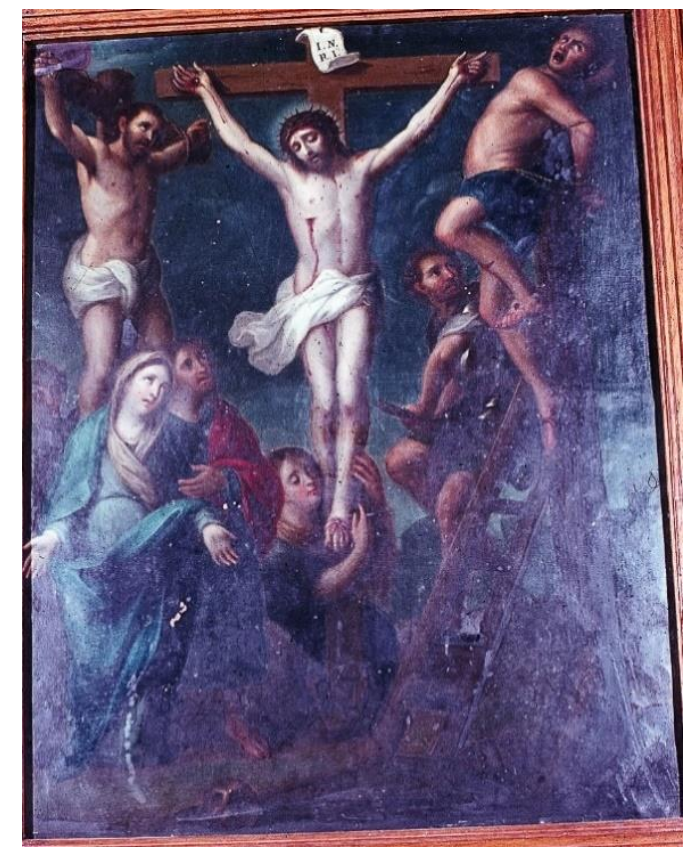

Fig. 11. José de Alcíbar, atribuido, Muerte de Cristo. Sacristía, La Profesa, Ciudad de México. (C) Fotógrafo Rafael Rivera. Archivo Fotográfico "Manuel Toussaint", Instituto de Investigaciones Estéticas, UNAM. (Reproducción autorizada por el Instituto Nacional de Antropología e Historia)

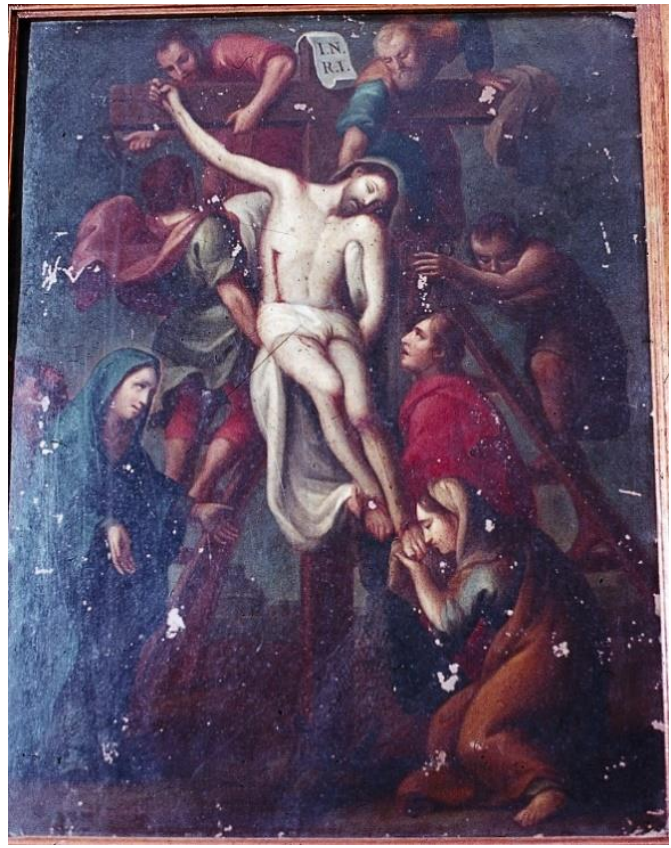

Fig. 12. José de Alcíbar, atribuido, Descendimiento de la cruz. Sacristía, La Profesa, Ciudad de México. (C) Fotógrafo Rafael Rivera. Archivo Fotográfico "Manuel Toussaint", Instituto de Investigaciones Estéticas, UNAM. (Reproducción autorizada por el Instituto Nacional de Antropología e Historia)

Durante la época colonial fue muy frecuente que algunos individuos hicieran, desde España, el duro viaje hacia América en busca de riquezas y fama. También fue habitual la migración de regreso de los expatriados desde México hacia España durante los años de las guerras de Independencia. El estudio de la serie de la Pasión de José de Ibarra se plantea, en este sentido, en este cruce de caminos.

Los catálogos de los artistas novohispanos permanecen muchas veces incompletos porque muchas obras siguen en colecciones privadas, cuyo acceso no es siempre fácil y por lo mismo no siempre se dan a conocer. La serie de la Pasión de José de Ibarra se integra perfectamente en la tradición pictórica novohispana de la que surgió. A esta coyuntura se añade el hecho de que ha permanecido en manos de la misma familia durante varias generaciones. El darse a conocer permitirá proponer nuevas hipótesis de investigación sobre la obra del gran maestro de la pintura novohispana, José de Ibarra. 
Bibliografía
Abreviaturas
IIE $=$ Instituto de Investigaciones Estéticas
UNAM = Universidad Nacional Autónoma de México

Álcala y Brown 2014: Luisa Elena Álcala y Jonathan Brown, ed. Painting in Latin America, 1550-1820, (New Haven: Yale University Press, 2014).

Bargellini 1995: Clara Bargellini, "'Amoroso horror"': arte y culto en la serie de la Pasión de Gabriel de Ovalle de Guadalupe, Zacatecas" en Arte y violencia, ed. Arturo Pascual Soto, (Ciudad de México: UNAM/ IIE, 1995), pp. 499-524.

Bargellini 2006: Clara Bargellini, "Consideraciones acerca de las firmas de pintores novohispanos" en El proceso creativo, XXVI Coloquio Internacional de Historia del Arte, ed. Alberto Dallal, (Ciudad de México: UNAM/ IIE, 2006), pp. 203-222.

Bargellini 2009: Clara Bargellini, "Difusión de modelos: grabados y pinturas flamencos e italianos en territorios americanos" en Pintura de los reinos. Identidades compartidas. Territorios del mundo hispánico, siglos XVI-XVIII, vol. 3. ed. Juana Gutiérrez Haces et al., (Ciudad de México: Fomento Cultural Banamex, 2009), pp. 965-1005.

Bargellini 2012: Clara Bargellini, "El artista 'inventor' novohispano" en Nombrar y explicar: La terminología en el estudio del arte ibérico y latinoamericano, ed. Patricia Díaz cayeros et al., (Ciudad de México, UNAM/ IIE, 2012), pp. 121-138.

Bargellini 2016: Clara Bargellini, et al. "Un álbum de grabados antiguos del Fondo Reservado de la Biblioteca Nacional de México" en Memorias del Congreso Internacional: Las edades del libro, ed. Marina Garone Gravier, et al., (Ciudad de México: UNAM, 2016), pp. 355-392.

Booker 1988: Jackie R. Booker, "The Veracruz Merchant Community in Late Bourbon Mexico: A Preliminary Portrait, 1770-1810", The Americas, 45, 2, (1988), pp. 187-199.

Cabrera 1756: Miguel Cabrera, Maravilla americana y conjunto de raras maravillas... (Ciudad de México: Imprenta Real y más antiguo Colegio de San Ildefonso, 1756).

Corvera y Ortiz 2011: Marcela Corvera Poiré y Elisa Ortiz Hernández, "Matthaus Merian y Antonio Tempesta en la Nueva España" en Amans artis, amans veritatis, Coloquio internacional de arte e historia en memoria de Juana Gutiérrez Haces, ed. Gustavo Curiel, (Ciudad de México: UNAM/ IIE/ Facultad de Filosofía y Letras/ Fomento Cultural BANAMEX, 2011), pp. 289307.

Cuadriello 2004: Jaime Cuadriello, "Una Biblia para el Nuevo Mundo: La Conquista de México y los emblemas políticos de Mattäeus Merian" en 
Florilegio de Estudios de Emblemáticas. Actas del VI Congreso Internacional de Emblemática/ The Society for Emblem Studies, ed. Sagrario López Poza, (La Coruña: Sociedad de Cultura Valle Inclán, 2004), pp. 33-48.

Deans-Smith 2007: Susan Deans-Smith, "'This Noble and Illustrious Art': Painters and the Politics of Guild Reform in Early Modern Mexico City, 16741768" En Mexican Sounding. Essays in Honour of David A. Brading, eds. Susan Deans-Smith y Eric Van Young, (London: Institute for the Study of the Americas, 2007), pp. 67-98.

Flores García 2013: Karina Lisette Flores García, El quehacer artístico-social de pintor novohispano: José de Alzíbar, /tesis doctoral). Escuela Nacional de Antropología e Historia. Ciudad de México, 2013).

González de Cossio 1950: Francisco González de Cossio, ed. Gacetas de México. vol. 2, (Ciudad de México: Secretaría de Educación Pública, 1950).

Gutiérrez 2001: Juana Gutiérrez, "Veracruz colonial en el siglo XVIII," Museo de arte del Estado de Veracruz, (Ciudad de México/ Veracruz: Fondo Cultural BANAMEX/ Gobierno del Estado de Veracruz, 2001), pp. 39-44.

Hyman 2017: Aaron M. Hyman, "Inventing Painting: Cristóbal de Villalpando, Juan Correa, and New Spain's Transatlantic Canon", The Art Bulletin, 99, 2, (2017), pp. 102-135.

Hyman 2017: Aaron M. Hyman, "Patterns of Colonial Transfer an Album of Prints in Mexico City", Print Quarterly, XXXIV, 4, (2017), pp. 393-399.

Iguíniz 1951: Juan B. Iguíniz, Breve historia de la Tercera Orden Franciscana en la Provincia del Santo Evangelio de México, desde sus orígenes hasta nuestros días, (Ciudad de México: Patria, 1951).

Katzew 2017: Painted in Mexico, 1700-1790: Pinxit Mexici, ed. Ilona Katzew, (Los Angeles/ Ciudad de México: Los Angeles County Museum of Art/ Fomento Cultural Banamex, 2017).

Kügelgen 2009: Helga Von Kügelgen, "La pintura de los reinos y Rubens" en Pintura de los reinos. Identidades compartidas. Territorios del mundo hispánico, siglos XVI-XVIII, ed. Juana Gutiérrez Haces, et al., (Ciudad de México: Fomento Cultural Banamex, 2009), vol. 3, pp. 1008-1078.

Manrique 2001: Jorge Alberto Manrique, "Una colección: un museo," Museo de arte del Estado de Veracruz, (Ciudad de México/ Veracruz: Fondo Cultural BANAMEX/ Gobierno del Estado de Veracruz, 2001), pp. 23-34.

Miegroet 2008: Hans J. Van Miegroet, "Copies-fantômes et culture de l'imitation au debut de l'époque moderne en Europe" en L'estampe un art multiple à la portée de tous?, ed. Sophie Raux, Nicolas Surlapierre, Dominique Tonneau-Ryckelynck, (Villeneuve d'Ascq: Presses Universitaires du Septentrion, 2008), pp. 47-64.

Moyssén 1965: Xavier Moyssén, "La primera academia de pintura en México", Anales del Instituto de Investigaciones Estéticas, 9, 34, (1965), pp. 15-29. 
Mues Orts 2001: Paula Mues Orts, José de Ibarra. Profesor de la nobilísima arte de la pintura, (Ciudad de México: Consejo Nacional para la Cultura y las Artes, 2001).

Mues Orts 2006: Paula Mues Orts, ed., El arte maestra: traducción novohispana de un tratado pictórico italiano, (Ciudad de México: Museo de la Basílica de Guadalupe, 2006).

Mues Orts 2008: Paula Mues Orts, La libertad del pincel. Los discursos sobre la nobleza de la pintura en Nueva España, (Ciudad de México: Universidad Iberoamericana, 2008).

Mues Orts 2009: Paula Mues Orts, El pintor novohispano José de Ibarra: Imágenes retóricas y discursos pintados, (tesis doctoral). UNAM. Facultad de Filosofía y Letras, UNAM. Ciudad de México, 2009.

Mues Orts, 2012: Paula Mues Orts, "De Murillo al murillismo o del cambio en la mirada: guiños sobre la suavidad y la gracia en la pintura novohispana" en Andalucía en América Arte y Patrimonio, ed. Rafael López Guzmán, (Granada: Editorial Atrio, 2012), pp. 47-72.

Mues Orts 2017: Paula Mues Orts, "Illustrious Painting and Modern Brushes" en Painted in Mexico, 1700-1790: Pinxit Mexici, ed. Ilona Katzew, (Los Angeles/ Ciudad de México: Los Angeles County Museum of Art/ Fomento Cultural Banamex, 2017), pp. 52-75.

Mues Orts 2017: Paula Mues Orts, "Sixth Station of the Cross", en: Painted in Mexico, 1700-1790: Pinxit Mexici, ed. Ilona Katzew, (Los Angeles/ Ciudad de México: Los Angeles County Museum of Art/ Fomento Cultural Banamex, 2017), pp. 209-210.

Navarrete Prieto 1998: Benito Navarrete Prieto, La pintura andaluza del siglo XVII y sus fuentes grabadas, (Madrid: Fundación de Apoyo a la Historia del Arte Hispánico, 1998).

Pérez Calero 1982: Gerardo Pérez Calero, "Dos obras desconocidas del pintor mejicano José Ibarra," Gades, Revista del Colegio Universitario de Filosofía y Letras de Cádiz, 9, (1982), pp. 267-270.

Robin 2006: Alena Robin, "El retablo de Xaltocán, las Imágenes de Jerónimo Nadal y la Monja de Ágreda", Anales del Instituto de Investigaciones Estéticas, XXVIII, 88, (2006), pp. 53-70.

Robin 2010: Alena Robin, "La Pasión de Cristo según José de Alcíbar (Museo de Arte Sacro, Chihuahua, México)", Via Spiritus, Revista de História da Espiritualidade e do Sentimento Religioso, 17, (2010), pp. 197-228.

Robin 2012: Alena Robin, "Vía Crucis y series pasionarias en los virreinatos latinoamericanos", Goya, 339, (2012), pp. 130-145.

Robin 2014: Alena Robin, Las capillas del Vía Crucis de la ciudad de México. Arte, patrocino y sacralización del espacio, (Ciudad de México: UNAM/ IIE, 2014). 
Ruiz Gomar 2004: Rogelio Ruiz Gomar, "Unique Expressions. Painting in New Spain" en Painting a New World, ed. Donna Pierce, Rogelio Ruiz Gomar, Clara Bargellini, (Denver: Denver Art Museum, 2004), pp. 47-77.

Schenone 1998: Héctor Schenone, Iconografía del arte colonial. Jesucristo, (Buenos Aires: Fundaciones Tarea, 1998).

Valverde Ramírez 2009: Maricela Valverde Ramírez, Ignacio Berben, un pintor del Reino de la Nueva Galicia, siglo XVIII, (Zacatecas: Universidad Autónoma de Zacatecas/ Gobierno del Estado de Zacatecas, 2009).

Vargaslugo 1985-2017: Elisa Vargaslugo, et al., Juan Correa. Su vida y su obra, 4 vols., (Ciudad de México: UNAM/ IIE, 1985-2017).

Enviado: 5/10/2019

Aceptado: $21 / 10 / 2019$ 